\title{
BUSH, OBAMA AND BEYOND: OBSERVATIONS ON THE PROSPECT OF FACT CHECKING EXECUTIVE DEPARTMENT THREAT CLAIMS BEFORE THE USE OF FORCE
}

\author{
Leslie Gielow Jacobs*
}

\section{INTRODUCTION}

Threats are scary. When they are real we should, of course, as a Nation address them, with force if necessary. When they are not, however, they should be exposed as what they are before the use of force. But, as the Iraq War experience demonstrates most recently, the fact checking that is essential to ensure the accuracy of executive department threat claims is not happening. Rather, a pattern has developed whereby Presidents persuade the Nation to consent to the use of force based upon threat claims for which they are effectively unaccountable until after the decision has been made. ${ }^{1}$ Although presidents may legitimately advocate persuasively in support of their chosen policy, the Constitution identifies the people, through Congress, as the

* Professor of Law, University of the Pacific, McGeorge School of Law. Thanks to the following people for helpful comments on earlier drafts: Bill Banks, Anne Bloom, Kathleen Clark, Michael Colatrella, Richard Collins, Heidi Kitrosser, Brian Landsberg, Thom Main, Elizabeth Rindskopf Parker and Kevin Stack. Thanks to Matthew Downs, Michael Claiborne and Rebecca Whitfield for excellent research assistance.

1. Whether or not the existence of these threats explained the administration's push for war, they were the primary reasons for the use of force offered by the President and other executive branch officials in their advocacy. See JOHN DIAMOND, THE CIA AND THE CULTURE OF FAILURE 13 (2008) ("The Bush team genuinely believed that Iraq had some banned weapons .... But the administration considered Iraqi weaponry to be a manageable threat. The problem was the future and what Iraq might do with its oil money once it was free from the crushing international sanctions."); see also Associated Press, Wolfowitz Comments Revive Doubts over Iraq's WMD, USA TODAY, June 1, 2003, http://www.usatoday.com/news/world/iraq/2003-05-30-wolfowitz-iraq_x.htm ("[W]e settled on the one issue that everyone could agree on which was weapons of mass destruction as the core reason." (quoting Paul Wolfowitz)); S. REP. No. 110-345, at 1 (2008), available at http://intelligence.senate.gov/pdfs/110345.pdf (reviewing executive department threat claims and characterizing them as "central to the nation's decision to go to war"). 
ones who must decide whether the president's choice is the right one. ${ }^{2}$ That presidents can routinely make threat claims without contemporaneous accountability represents a failure of democracy in the use-of-force decision making and oversight process, since informed consent requires that the decision makers understand at least the basic facts upon which the President's proposed policy is based.

Part I sets out the experience of the last Administration's use of inflated threat claims to persuade the country to consent to the use of force in Iraq. Against this backdrop, Part II compares the current President's use of threat claims and the effectiveness of the mechanisms for fact checking his persuasive advocacy in support of the use of force in Afghanistan. Although the comparison must be imperfect, it supports the observation that, while different office holders may make different choices, the structures and incentives that have in the past allowed executive branch officials to assert unverified threats as certain and sufficient to justify the use of force have not changed significantly. While certain types of legal reforms could help to impose accountability on executive branch actors who make threat claims, they are both unlikely to be enacted or, if enacted, to be effectively enforced, at least in the short term. In response to this reality, Part III proposes that some progress toward the elusive goal of effective democratic use of force decision making can be achieved by approaching the problem of potentially inflated executive department threat claims from the other side of the communication exchange. Several key recognitions about the nature of use of force advocacy and the secret intelligence information that executive branch actors may offer to support it, and about the incentives of surrogates who can help interpret what that information means, can help shore up listener defenses to

2. The Constitution grants Congress the power to "declare War" and other powers that indicate the Framers intended it to actively oversee use of force decision making. U.S. CONST. art. I, $\S 8$ (Congress's powers related to use of force policy making include: "[To] provide for the common Defence and general Welfare of the United States," "To declare War," "To raise and support Armies," "To provide and maintain a Navy," "To make Rules for the Government and Regulation of the land and naval Forces."). Debates among the Framers reinforce the conclusion that this allocation of responsibility reflects a considered judgment that, absent a sudden attack that requires immediate action, the deliberative processes of Congress should be the ones through which the consent of the people to use of force is obtained, and that such deliberation was to act as a check on an eager, aggressive, and potentially persuasive executive. Louis Fisher, Unchecked Presidential Wars, 148 U. PA. L. REV. 1637, 1651 (2000). But see John C. Yoo, The Continuation of Politics by Other Means: The Original Understanding of War Powers, 84 CAL. L. REV. 167 (1996) (the framers intended that the President be able to initiate wars). 
government speech, and specifically threat claims, and thereby bolster the contemporaneous accountability of use of force advocacy.

\section{USE OF FORCE ADVOCACY, THREAT CLAIMS AND THE LACK OF CONTEMPORANEOUS ACCOUNTABILITY BEFORE THE IRAQ WAR}

The Iraq War experience illustrates the government structures, incentives, and behaviors that now unite in "perfect storm" combination to lead to the result that executive branch actors can make threat claims in support of the use of force for which they are effectively unaccountable until after the policy choice is made.

Aggressive and Persuasive Use of Threat Claims in Support of the Use of Force. Modern presidents exist at the center of increasingly massive, multi-faceted communications machines. ${ }^{3} \mathrm{Al}-$ though one purpose of executive branch communications is to provide information to the public, a fundamental unabashed purpose is to advocate for the President's policies. Engaging in persuasive government speech is a crucial component of the exercise of any President's constitutional authority. The President enjoys an advocacy advantage over any other communicators in the Nation, and, arguably, the world. He is a single person, and can coordinate executive branch messages. ${ }^{4} \mathrm{He}$ has a vast staff to keep track of the many sources of information dispersal and to keep them in line. Although one-sided and aggressive, persuasive presidential speech is a legitimate and appropriate tool for governing because the President, like other government speakers, operates under a democratic mandate to implement policies through all legal and effective means, including speech, and he is accountable to those he governs for the content of his speech. ${ }^{5}$

3. Martha Joynt Kumar, Managing the President's Message 4-6 (2007) (describing how the President's communication operations have grown through several administrations).

4. See Eric A. Posner \& Adrian Vermeule, The Credible Executive, 74 U. CHI. L. REV. 865, 886 (2007) ("[T]he executive can act with much greater unity, force and dispatch than can Congress, which is chronically hampered by the need for debate and consensus among large numbers.").

5. Democratic accountability is the important attribute that distinguishes the Free Speech Clause category of "government speech." Pleasant Grove City v. Summum, 129 S. Ct. 1125, 1132 (2009) (noting that a government entity is ultimately "accountable to the electorate and the political process for its advocacy" (quoting Board of Regents v. Southworth, 529 U.S. 217, 235 (2000)). While the Constitution limits government control of private speech, government actors may engage in "government speech" that advocates in favor of some and discriminates against other controversial viewpoints. Pleasant 
The President bears the constitutional responsibility to discern threats to homeland security and to address them. ${ }^{6}$ Like all actions of a democratic government, the use of force should occur with the consent of the governed to the President's proposed policy, informed by an understanding of the facts that support the choice. Consequently, Presidents may legitimately and appropriately advocate that immediate and grave threats to homeland security exist for the purpose of persuading those he governs to consent to the use of force.

In the year before the Iraq War, President Bush, in combination with others in his Administration, used threat claims as the primary component of a strategic and coordinated communications campaign to build consent to his policy choice to use force. These communications included formal speeches, ${ }^{7}$ media interviews, ${ }^{8}$ congressional briefings, ${ }^{9}$ and documents delivered to Congress and released publicly. ${ }^{10}$ In these communications, ex-

Grove, 129 S. Ct. at 1131 (government may "select the views that it wants to express"). "Accountability" means that the process by which the message is created is subject to "political safeguards," and that a "politically accountable official" or politically accountable body is responsible for the content. Johanns v. Livestock Mktg. Ass'n, 544 U.S. 550, 563-64 (2005). Effective accountability means that the electorate can understand, evaluate and react to government speech. Pleasant Grove, 129 S. Ct. at 1132 ("If the citizenry objects, newly elected officials later could espouse some different or contrary position." (quoting Southworth, 529 U.S. at 235)). Enforcing structures of accountability is a principle that underpins decisions with respect to other parts of the Constitution. See Clinton v. City of New York, 524 U.S. 417 (1998) (line item veto); New York v. United States, 505 U.S. 144 (1992) (commandeering); INS v. Chadha, 462 U.S. 919 (1983) (legislative veto). 2, cl. 1 .

6. The President is Commander-in-Chief of the armed forces. U.S. CONST. art. II $\S$

7. S. REP. NO. 110-345, at 5, available at http://intelligence.senate.gov/phaseiiaccuracy. pdf (quoting President Bush's 2003 State of the Union Address, in which he stated, "the British government has learned that Saddam Hussein recently sought significant quantities of uranium form Africa"); id. (quoting President Bush's speech in Cincinnati on Oct. 7, 2002, in which he stated that Saddam Hussein was "moving ever closer to developing a nuclear weapon" and that Iraq "could have a nuclear weapon in less than a year").

8. James Gerstenzang, Bush Promises Postwar Aid if Hussein Toppled, L.A. TIMES, Oct. 6, 2002, at 21 ("Delay, indecision and inaction are not options for America, because they could lead to massive and sudden horror." (quoting President Bush)). Deborah Orin, Iraq Slams the Door: Rejects New U.N. Orders on Weapons, N.Y. PoST, Sept. 29, 2002, at 4 ("The dangers we face will only worsen from month to month and year to year. To ignore these threats is to encourage them." (quoting President Bush's Sept. 28 radio address)).

9. See H.R. Doc. No. 107-229 (2002) (in a statement made by President Bush to the House of Representatives about proliferation of weapons of mass destruction he said that nuclear activity in Iraq is believed to have continued since the UN inspections stopped in December 1998); see also H.R. DoC. No. 107-175 (2002) (President Bush urged for the deployment of troops against Saddam Hussein's "record of aggressive behavior" in order to acquire Iraq's weapons of mass destruction, to protect Iraq's neighbors and protect the Kurds in the northern region).

10. See 145 CONG. REC. E1545-46, E1567 (statements of Rep. King) (including in 
ecutive branch officials repeatedly asserted as true that the Iraq (1) possessed the weapons capacity to pose an actual and immediate threat to the security of neighboring nations and the United States; (2) possessed means of delivering the existing weapons into neighboring countries, and perhaps into the United States; (3) was inclined to attack other countries, including the United States; and (4) was offering support, including weapons, to nonnation terrorist organizations, including al-Qaeda, which perpetrated the September 11, 2001 attacks. ${ }^{11}$ Various sources have compiled the hundreds of these types of threat claims made by Bush Administration officials during the lead-up to the Iraq War. ${ }^{12}$ Examples include the following:

The Iraqi regime possesses biological and chemical weapons, is rebuilding the facilities to make more and, according to the British government, could launch a biological or chemical attack in as little as 45 minutes after the order is given... This regime is seeking a nuclear bomb, and with fissile material could build one within a year. ${ }^{13}$

Simply stated, there is no doubt that Saddam Hussein now has weapons of mass destruction. There is no doubt he is amassing them to use against our friends, against our allies, and against us. ${ }^{14}$

We know that Iraq and al Qaeda have high-level contacts that go back a decade.... We've learned that Iraq has trained al Qaeda members in bomb-making and poisons and deadly gases. ${ }^{15}$

The Iraqi regime ... possesses and produces chemical and bi-

the record the unclassified version of the October 2002 National Intelligence Estimate that was delivered to Congress in classified version and released publicly in unclassified form).

11. See S. REP. NO. 110-345, supra note 1.

12. See COMMITTEE ON GOVERNMENT REFORM, IRAQ ON THE RECORD, 108th Cong., Report on The Bush Administration's Public STATEMENTS ON IRAQ 5 (Comm. Print 2004); Charles Lewis \& Mark Reading-Smith, False Pretenses, CTR. FOR PUB. INTEGRITY, Jan. 23, 2008, http://projects.publicintegrity.org/WarCard/ ("President George W. Bush and seven of his administration's top officials, including Vice President Dick Cheney, National Security Adviser Condoleezza Rice, and Defense Secretary Donald Rumsfeld, made at least 935 false statements in the two years following September 11, 2001, about the national security threat posed by Saddam Hussein's Iraq.").

13. President George W. Bush, The President's Radio Address, 38 WEEKLY COMP. PRES. DOC. 1656, 1657 (Sept. 28, 2002).

14. Vice President Dick Cheney, Address to the National Convention of the Veterans of Foreign Wars (Aug. 26, 2002), available at http://georgewbushwhitehouse.archives.gov/news/releases/2002/08/20020826.html.

15. President George W. Bush, Address to the Nation on Iraq From Cincinnati, Ohio, 38 WEEKLY COMP. PRES. DOC. 1716, 1717 (Oct. 7, 2002). 
ological weapons. It is seeking nuclear weapons.... We could wait and hope that Saddam does not give weapons to terrorists, or develop a nuclear weapon to blackmail the world. But I'm convinced that is a hope against all evidence. ${ }^{16}$

Additionally, executive department advocates strategically planned their rhetoric and presentations to make use of "gripping images," such as the "smoking gun" that might be a "mushroom cloud," the lump of material "a little larger than a single softball" that could become a nuclear weapon, ${ }^{18}$ and the vial of "anthrax" wielded by Secretary of State Colin Powell to illustrate the claims made in his United Nations Security Council speech. ${ }^{19}$

The Bush Administration presented facts about threats posed by Iraq for the purpose of influencing the public discussion and conclusions about the policy the President advocated and sought to have the Nation embrace. By presenting threats posed by Iraq as actual, imminent, and potentially directed at the homeland, the President and his advisors were able to argue that war was a necessity not a choice. ${ }^{20}$ By means of threat claims, the Administration was able to present the justifications for war as simple and concrete, ${ }^{21}$ and in terms that invoked patriotism ${ }^{22}$ and

16. S. REP. NO. 110-345, supra note 1, at 4-5 (quoting President George W. Bush, supra note 15 , at 1716,1719$)$.

17. RICHARD A. BEST, JR., CRS REPORT FOR CONGRESS: U.S. INTELLIGENCE AND POLICYMAKING 6 n.15 (2005), available at http://www.fas.org/sgp/crs/intel/RS21696.pdf (citing Barton Gellman \& Walter Pincus, Depiction of Threat Outgrew Supporting Evidence, WAsh. Post, Aug. 10, 2003, at A1); see also Bush Cites Saddam's 'Arsenal of Terror', CNN, Oct. 8, 2002, http://archives.cnn.com/2002/ALLPOLITICS/10/07/bush.iraq/ index.html ("Facing clear evidence of peril we cannot wait for the final proof-the smoking gun-that could come in the form of a mushroom cloud." (quoting George W. Bush)); Wolf Blitzer, Search for the Smoking Gun, CNN, Jan. 10, 2003, http://www.cnn.com/2003/US/01/10/wbr.smoking.gun ("The problem here is that there will always be some uncertainty about how quickly he can acquire nuclear weapons. But we don't want the smoking gun to be a mushroom cloud." (quoting Condoleeza Rice in 2002)).

18. President George W. Bush, supra note 15, at 1718 ("If the Iraqi regime is able to produce, buy, or steal an amount of highly enriched uranium a little larger than a single softball, it could have a nuclear weapon in less than a year.").

19. See, e.g., The Record on Curveball: Declassified Documents and Key Participants Show the Importance of Phony Intelligence in the Origins of the Iraq War, NAT'L SECURITY ARCHIVE, Nov. 5, 2007, http://www.gwu.edu/ nsarchiv/NSAEBB/ NSAEBB234/index.htm.

20. John M. Schuessler, Deception and the Iraq War 8-14 (Aug. 28, 2008), (unpublished paper presented at the APSA 2008 Annual Meeting), available at http://www.allacademic.com/meta/p_mla_apa_research_citation/2/7/9/1/1/p279113_index. html see also Chaim Kaufmann, Threat Inflation and the Failure of the Marketplace of Ideas, 29 INT'L SECURITY 5, 7-8 (2004), available at http://belfercenter.ksg.harvard.edu/ files/kaufmann. pdf.

21. See Jeffrey M. Cavanaugh, From the 'Red Juggernaut' to Iraqi WMDs: Threat 
emotions, ${ }^{23}$ all important elements to garnering public support for a complex and costly foreign commitment.

The Bush Administration's threat advocacy was designed to build consent to the use of force and it did so. A chart produced in a House Report records the number of statements about the Iraq threat made by executive department officials sharply peaking in the several weeks before Congress voted to authorize the President to use force. ${ }^{24}$ The Report of the House Committee on International Relations explained that it embraced the executive branch's factual assertions about the Iraq threat and based its recommendation that the body vote to authorize the use of force upon it. ${ }^{25}$ Individual House Members and Senators who had initially expressed reluctance to consent to the use of force explained their votes in favor as based on their belief that the threat claims advocated by the executive department were true. ${ }^{26}$

Inflation and How It Succeeds in the United States, 122 POL. SCI. Q. 555, 566 (2007) ("Apathy, ignorance, and the cost of acquiring quality sources of information are disincentives mitigating public willingness to examine an administration's foreign policy in detail."); see also John Zaller, Elite Leadership of Mass Opinion, in TAKEN BY STORM 186, 188 (W. Lance Bennett \& David L. Paletz eds., 1994) ("Few members of the general public should be expected to engage in independent thought and analysis on foreign policy issues. The most that can be expected is that they choose among competing elite and media messages.").

22. One incentive to make threat claims is the "rally around the flag" bump in public popularity that Presidents tend to achieve when they forcefully confront an enemy. John E. Mueller, WAR, Presidents AND Public OPINION 58-59 (1973). See also Jane K. Cramer, Militarized Patriotism and the Success of Threat Inflation, in AMERICAN FOREIGN POLICY AND THE POLITICS OF FEAR 135, 137 (A. Trevor Thrall \& Jane K. Cramer eds., 2009) (presenting extensive evidence, with respect to the Iraq War vote, to support the claim that "most Democrats and many Republicans deferred to the executive branch not on the merits of the case, but because they did not want to appear weak on defense or unpatriotic"); George McGovern, Patriotism is Nonpartisan, NATION, Apr.1, 2005, at 30, available at http://www.thenation.com/article/patriotism-nonpartisan.

23. Advocacy that includes threat claims may be particularly potent because of the public tendency to systematically overvalue low probability/high impact threats, such as terrorism. Jonathan S. Masur, Probability Thresholds, 92 IOWA L. REV. 1293, 1323-24 (2007) (making this argument in the context of official claims that speech will cause a national security threat).

24. COMMITTEE ON GOVERNMENT REFORM, IRAQ ON THE RECORD, 108th CONG., REPORT ON THE Bush AdMINISTRATION'S PUbliC STATEMENTS ON IRAQ 5 (Comm. Print 2004).

25. H.R. REP. No. 107-721, at 7-8 (2002), reprinted in 2002 U.S.C.C.A.N. 1001 ("Iraq both poses a continuing threat to the national security of the United States and international peace and security in the Persian Gulf region and remains in material and unacceptable breach of its international obligations by, among other things, continuing to possess and develop a significant chemical and biological weapons capability, actively seeking a nuclear weapons capability, and supporting and harboring terrorist organizations. ... The continuing threat posed by Iraq is the motivation for the Committee's favorable action on [the proposed joint resolution to authorize the use of force].").

26. See Thomas Oliphant, Op-Ed., Bush's Victory Cost Plenty, Boston Globe, Oct. 13, 2002, at D11 (reluctant Bush supporters Senators Chuck Hagel, John Kerry and 
Following the October 2002 votes by Congress to authorize the use of force, ${ }^{27}$ the executive department continued to engage in advocacy about the threat posed by Iraq. The President used his January 2003 State of the Union address as a platform to advocate the multiple threats posed by Iraq ${ }^{28}$ and in his February address to the United Nations Security Council, Secretary of State Colin Powell presented detailed threat claims to the world. ${ }^{29}$ Public opinion polls indicate that these advocacy efforts moved public opinion in favor of the use of force against Iraq. ${ }^{30}$ In particular, public support for the use of force in Iraq correlated with believing executive department threat claims. ${ }^{31}$

We know now that these threat claims were not true. ${ }^{32}$ Instead, Congress and the American people gave their consent to use of force in Iraq based at least in significant part upon inflated threat claims. ${ }^{33}$ One source of threat inflation were the raw intelligence and assessments offered by parts of the intelligence community, which grew increasingly urgent and dire over the

Hillary Rodham Clinton gave yes votes to the use of force by taking President Bush at his word).

27. Alison Mitchell \& Carl Hulse, Congress Authorizes Bush to Use Force Against Iraq, N.Y. TIMES, Oct. 11, 2002, at A1, available at http://www.nytimes.com/2002/10/ 11/national/11IRAQ.html?pagewanted=all.

28. George W. Bush, President of the U.S., State of the Union Address (Jan. 28, 2003) available at http:/www.cnn.com/2003/ALLPOLITICS/01/28/sotu.transcript/.

29. Colin Powell, Secretary of State, Address to United Nations Security Council (Feb. 5, 2003), available at http://www.cnn.com/2003/US/02/05/sprj.irq.powell.transcript/.

30. Kaufmann, supra note 20, at 30. An October 2002 Pew Research Center Report on public opinions noted "broad agreement that Saddam Hussein either already has or is close to having nuclear weapons." Generations Divide over Military Action in Iraq, PEW RESEARCH CTR., Oct. 17, 2002, http://people-press.org/commentary/?analysisid=57. In February 2003 Pew recorded that the combination of President Bush's State of the Union address and Secretary of State Colin Powell's presentation to the United Nations had significantly moved United States public opinion in favor of military action against Iraq, with four separate polls showing that a majority of Americans judged that the Bush administration had made a "convincing case." Powell Reversed the Trend but not the Tenor of Public Opinion, PEW RESEARCH CTR., Feb. 14, 2003, http://peoplepress.org/commentary/?analysisid=62. But see GEORGE EDWARDS, ON DEAF EARS ix, xi (2003) (reproducing Gallup Poll results to support his conclusion that in response to the President's "rhetorical efforts" to support war in Iraq, "public opinion barely moved").

31. STEVEN KULl, MisPerceptions, THE MEdia AND THE IRAQ WAR 2 (2003), available at http://www.worldpublicopinion.org/pipa/pdf/oct03/IraqMedia_Oct03_rpt.pdf.

32. See S. REP. NO. 109-331 (2006).

33. Threat inflation "is the attempt by elites to create concern for a threat that goes beyond the scope and urgency that a disinterested analysis would justify. Jane K. Cramer \& A. Trevor Thrall, Introduction, in AMERICAN FOREIGN POLICY AND THE POLITICS OF FEAR 1, 1 (A. Trevor Thrall \& Jane K. Cramer eds., 2009). A simple model of the threat inflation process proceeds as follows: "elites perceive threats, create communication strategies to inflate threats, implement those strategies within the news media, or marketplace of ideas, in an attempt to shape opinions and influence policy, and either succeed or fail to do so." Id. at 2-3. 
course of the approximately 18 months between the September 2002 terrorist attacks and the beginning of the war against Iraq. ${ }^{34}$ The other source of threat inflation were the testimony, briefings and public statements of executive department officials, who repeatedly exaggerated the certainty, unanimity and imminence of the Iraq threats beyond those held by the intelligence community. ${ }^{35}$ Observers differ as to the underlying reasons for the threat inflation and the motivations of the executive branch officials who engaged in it. ${ }^{36}$ What is clear, however, is that the threat inflation communications campaign engaged in by the President and his close advisors to persuade Congress and the public to consent to his policy choice resulted in a failure of democratic governance. With the facts misunderstood, Congress members and the public consented to the use of force based upon a fundamental misunderstanding of the policy choice to be made.

And it is hardly the first time that this kind of misunderstanding has occurred. Instead, executive department threat inflation to build consent to the use of force has become a bleak pattern-some might call it a "winning strategy"-identified by many after the use of force and by some as it is ongoing, but not enough to redirect the public debate and deliberation toward the truth of the facts asserted and the real reasons that the executive branch advocates war. ${ }^{37}$ It is not obvious that this pattern can be

34. Joseph Cirincoine et al., WMD in Iraq: Evidence and Implications, CARNEGIE ENDOWMENT FOR INT'L PEACE, Jan. 2004.

35. See S. REP. NO. 110-345 (2008), supra note 1.

36. See Cramer \& Thrall, supra note 22, at 1-2 ("To date scholars have offered a wide range of arguments about why the Bush administration has sought to inflate threats since 9/11 and Iraq in particular. Many observers insist that much of the threat exaggeration since $9 / 11$ has been intentional, politically opportunistic and even self-serving. Others see the administration as sincere, led by long-held ideology to see the post 9/11 world as extremely threatening. Some scholars point the finger at neoconservatives in key positions; arguing that they pressed their worldview on the administration and hijacked the decision-making process regarding Iraq. Others have argued that common psychological short cuts in reasoning biased the threat perception process and most likely significantly account for the widespread misperceptions among administration leaders and their followers. Still others find the threat inflation process likely to be at root politically motivated, but nonetheless primarily institutionally determined and perhaps even necessary to exaggerate threats to enable bold foreign policy initiatives. Finally, a few scholars have assessed the post 9/11 era and found simply a series of heightened fears, unavoidable intelligence failures, and mistakes in judgment.").

37. See, e.g., JOHN QUIGLEY, THE RUSES FOR WAR 14 (1992) (documenting a pattern, since World War I, of executive department use of force advocacy that "omit[ted] inconvenient details and exaggerated hazards"); see also The Executive Accountability Act of 2009: Hearing Before the Crime Subcomm. of the H. Comm. on the Judiciary, 111th Cong. (2009), available at http://loc.gov/law/help/usconlaw/pdf/H.R.\%20743.testimony. 2009.pdf (statement of Louis Fisher, Specialist in Constitutional Law, Law Library of the Library of Congress); Id. app. A (documenting misleading justifications for war); 
broken. That it exists, however, suggests that understanding how it happened, in its most recent incarnation, is the first step toward determining whether the current government structures, incentives and behaviors create the possibility that it could happen again. Obtaining this understanding requires identifying the checks that were supposed to have been operating to render executive department officials contemporaneously accountable for their threat claims, and why these processes failed.

Information Control in Support of Threat Claims. One accountability check on executive department fact claims made in support of advocacy stems from the free speech guarantee, and the marketplace of ideas that it protects. Free speech leads to contemporaneous accountability of executive department fact claims according to a chain of assumptions and events because other actors, in and out of government, have access to the facts that bear upon the debate and have the incentive and ability to publicly contest the President's claims. That this information is available means that the President and his officials can be held contemporaneously accountable for what they say. That they understand that incorrect or incomplete fact claims can be exposed and if so, will undercut their credibility, dampens their incentives to misrepresent facts intentionally or inadvertently, and so encourages diligence and thoroughness in information gathering and assessment. Although most members of the public may not grasp the details of the policy decision to be made or be able or willing to verify the facts asserted independently, through debate filtered by credible experts they can understand the relevant facts and how they relate to the policy choice to be made, and can reach opinions and express preferences on the broad policy, which means that the laws that are made reflect the consent of those who are governed in this indirect way. ${ }^{38}$

A barrier to achieving this kind of contemporaneous accountability for threat claims asserted by the executive department to build support for the use of force is its superior access to and control over the intelligence information that forms the basis of the claims. Collecting intelligence information relevant to

Eugene SeCunda \& TERENCE P. MORAn, SElling WAR TO AMERICA 1(2007) ("[T]0 sell . . . wars, U.S. presidents regularly distort the truth and withhold crucial information from the public, exploiting whatever media and marketing techniques are available at the time.").

38. JOHN R. ZALler, The NATURE AND ORIGINS OF MASS OPINION (1992) (proposing the "elite discourse" model of public opinion formation discussed and applied here in the Iraq War context). 
assessing threats to national security is a government activity. Within the government, the intelligence agencies and military departments that gather and analyze intelligence information are under the direct control of the President. ${ }^{39}$ No other domestic entity-not Congress, not the media, not private organizationshas the ability to obtain intelligence information of the same volume, quality and timeliness or to provide comprehensive assessments of comparable credibility and authority. ${ }^{40}$ The President has the authority and responsibility to restrict public access to intelligence information for the purpose of protecting national security. ${ }^{41}$ To the extent that the President exercises his ability to limit access to the facts that he uses to advocate for his use of force policy, ${ }^{42}$ the free speech guarantee may be insufficient to provide a contemporaneous accountability check on the threat claims he makes.

Members of the Bush Administration exercised their ability to control access to threat assessment information to support their pro-war advocacy in two separate, but related, ways. First, administration officials controlled release of the entire body of

39. See generally Intelligence.gov, http://intelligence.gov/about-the-intelligencecommunity/ (setting out the structure of the intelligence community).

40. Memorandum from Alfred Cumming, Specialist in Intelligence and Nat'l Sec., Cong. Research Serv., to Senator Dianne Feinstein (Dec. 14, 2005), http://feinstein.senate.gov/crs-intel.htm (the President and his most senior advisors have access to more and better intelligence, and they are better positioned to judge its quality and to request that inconclusive information be expanded or supplemented). In particular, Congress does not have access to the President's Daily Brief, or to the meeting in which it is presented, which allows the President "full access to intelligence community officials and provides a set time each day when he can ask senior intelligence officials about the basis for their judgments." Walter Pincus, Lawmakers Focus on Daily Brief In Prewar Intelligence Debate, WASH. POST, Nov. 19, 2005, at A5, available at http:/www.washingtonpost.com/wp-dyn/content/article/2005/11/18/AR2005111802578.

html. A member of the Senate Intelligence Committee confirms that intelligence agencies do not readily volunteer information. To get it, "you have to ask the right questions." Dana Priest, Congressional Oversight of Intelligence Criticized, WASH. POST, Apr. 27, 2004, at A1, available at http://www.washingtonpost.com/ac2/wp-dyn/A448372004Apr26?language=printer (quoting Sen. Mike DeWine).

41. See Exec. Order No. 13,526, 75 Fed. Reg. 707 (2009) (titled as "Classified National Security Information," prescribing "a uniform system for classifying, safeguarding, and declassifying national security information, including information relating to defense against transnational terrorism," which includes classification of information pertaining to "intelligence sources or methods"); KEVIN R. KOSAR, SECURITY CLASSIFICATION POLICY AND PROCEDURE: E.O. 12958, AS AMENDED (2009), available at http://assets.opencrs.com/rpts/97-771_20091231.pdf (describing the history of the classification system and the changes in President Obama's executive order).

42. The ability of the President and executive department agencies to classify information and prevent its release may extend well beyond their actual authority to do so. See, e.g., NAT'L COMM'N ON TERRORIST ATTACKS ON THE U.S., 9/11 COMMISSION REPORT 417, available at http://www.gpoaccess.gov/911/pdf/fullreport.pdf ("Current security requirements nurture overclassification."). 
threat assessment information to which they had access so that the information presented to Congress, the media and the public did not accurately reflect the contents of the information within their control, but instead supported the use of force policy. Second, administration officials controlled the process by which raw intelligence was collected and analyses produced so that the content of the information within their control changed, to more robustly support the use of force policy.

The President and his top officials relied on controlled information release in a number of ways to support their use of force advocacy. That they withheld much information within their control meant that they could rely upon the public's knowledge that they had superior access to the entire body of existing information to characterize the facts with greater certainty than the content of the information reflected, to omit mention of dissent, to suggest that they had more and better quality information than they presented, and to ask the public to embrace the truth of the threat claims based on trust rather than proof. ${ }^{43}$ They selectively released pieces of raw intelligence that supported their claims, ${ }^{44}$ without disclosing that intelligence experts disagreed about whether the evidence was significant or whether its source was credible. ${ }^{45}$ They did not release raw intelligence or intelligence community assessments that undercut their argument that Iraq presented an immediate threat. ${ }^{46}$ Top officials who had

43. Elisabeth Bumiller \& James Dao, Eyes On Iraq; Cheney Says Peril of A Nuclear Iraq Justifies Attack, N.Y. TIMES, Aug. 27, 2002, at A1, available at http://www.nytimes.com/2002/08/27/world/eyes-on-iraq-cheney-says-peril-of-a-nucleariraq-justifies-attack.html?pagewanted=all ("[T]here is no doubt that Saddam Hussein now has weapons of mass destruction. ... [T]here is no doubt that he is amassing them to use against our friends, against our allies and against us." (quoting Vice President Cheney)).

44. See Louis Fisher, Deciding on War Against Iraq, 118 PoL. SCI. Q. 389, 401 (2003) (describing selective declassification of satellite photographs purportedly demonstrating that Iraq was reconstituting its nuclear program); see also Murray Waas, Cheney 'Authorized' Libby to Leak Classified Information, NAT'L J., Feb. 9, 2006, available at http://www.nationaljournal.com/about/njweekly/stories/2006/0209nj1.htm ("Vice President Dick Cheney's former chief of staff, I. Lewis (Scooter) Libby, testified to a federal grand jury that he had been 'authorized' by Cheney and other White House 'superiors' in the summer of 2003 to disclose classified information to journalists to defend the Bush administration's use of prewar intelligence in making the case to go to war with Iraq.").

45. See S. REP. NO. 108-301, at 28-29 (2004), available at http://intelligence.senate. gov/108301.pdf (finding that the Director of Central Intelligence did not present dissenting views within the intelligence community about the significance of evidence purportedly demonstrating Iraq's ongoing efforts to create nuclear weapons to executive department policy makers); Joby Warrick, Evidence on Iraq Challenged; Experts Question if Tubes Were Meant for Weapons Program, WASH. Post, Sept. 19, 2002, at A18.

46. In the early months of 2002 , executive officials investigated suspicions that Iraq had attempted to obtain weapons grade uranium from Niger, including sending an emis- 
iterated facts that did not support administration policy came to embrace the alternative facts and articulate them publicly. ${ }^{47}$ Intelligence analysts did not generally dissent publicly. ${ }^{48}$ Those who spoke out generally did so anonymously, which undercut their credibility. ${ }^{49}$ Members of the executive branch enlisted private experts as "message multipliers," providing selective access to facts and policy so they could rearticulate them "in the form of their own opinions" when they appeared as "independent" media analysts. ${ }^{50}$ Officials also multiplied their own message by quoting information reporters had obtained from their own office and published as if it were an independent source. ${ }^{51}$ Additionally, Bush Administration officials delayed delivery of the information that they chose to release, which allowed the unrebutted executive department threat claims to become cemented in the public minds and made it difficult for members of Congress to effectively use the information to assess and challenge executive department advocacy before the vote to authorize the use of force.

sary to the country to investigate. Although the information that returned did not support the executive department's suspicions, it did not publicly release it. Walter Pincus, CIA Did Not Share Doubt on Iraq Data; Bush Used Report of Uranium Bid, WASH. PosT, June 12, 2003, at A1.

47. Zachary Colie, Powell to Leave Cabinet-Rice Likely to Move Up, S.F. CHRON., Nov. 16, 2004, at A1 ("During the build-up before the war, [Powell] urged the president to allow time for U.N. weapons inspectors to work and to build a broader coalition against Iraqi leader Saddam Hussein ... . . Despite his private disagreements, he staunchly defended the war. Powell went before the United Nations Security Council in February 2003 to make the administration's case that Hussein was concealing weapons of mass destruction."); Barbara Slavin \& John Diamond, Case is Stronger When 'Biggest Dove' Makes It, USA TODAY, Feb. 6, 2003, at 10A (reporting Powell's UN speech).

48. Mark Phythian, Intelligence Analysis Today and Tomorrow, 5 SECURITY CHALLENGES 67, 73-74 (2009), available at http://www.securitychallenges.org.au/ArticlePDFs/ vol5no1Pythian.pdf (noting the failure of intelligence agencies to include dissenting views internally).

49. S. REP. NO. 108-301, supra note 45, at 357.

50. See David Barstow, Behind TV Analysts, Pentagon's Hidden Hand, N.Y. TIMES, Apr. 20, 2008, at A1, available at http://www.nytimes.com/2008/04/20/us/20generals.html (these private experts acknowledged that they sometimes repeated inflated threat claims).

51. See Michael Massing, Now They Tell Us, N.Y. Rev. OF BooKs, Feb. 26, 2004, http://www.nybooks.com/articles/archives/2004/feb/26/now-they-tell-us/ (recounting how administration officials appearing on Sunday morning talk shows referred to information about Iraq's alleged pursuit of nuclear weapons that appeared in a front page New York Times story and that originated in the executive department as if it were independently corroborated information); Michael R. Gordon \& Judith Miller, Threats and Responses: The Iraqis; U.S. Says Hussein Intensifies Quest for A-Bomb Parts, N.Y. TIMES, Sept. 8, 2002, at A1.

52. See S. REP. No. 109-331, supra note 32, at 13-15 (describing process by which the October 2002 National Intelligence Estimate on Iraq's Continuing Programs for Weapons of Mass Destruction was requested and created). 
Members of the Bush Administration also used their control over the agencies and people who gather and analyze intelligence information to influence the content of the raw information gathered and the threat assessments to support their use of force policy. Most basically, executive department officials repeatedly suggested in their advocacy that intelligence information and assessments were driving policy conclusions, when the reverse appears to have been the case..$^{53}$ At the very least, members of the Bush Administration did not encourage the independent and thorough intelligent gathering and analysis that can be expected to produce the most accurate threat assessments. ${ }^{54}$ They did not challenge analysts to break out of the "group think," and "mindset," and poor tradecraft practices that had led to past intelligence failures, including the very recent failure to discover and prevent the 2001 al-Qaeda attacks, and which the Senate Select Committee on Intelligence found to have caused the Iraq misjudgments. ${ }^{55}$ Instead, executive department officials, particularly the Vice President, aggressively prodded intelligence analysts to discover information and provide threat assessments that would substantiate threat claims and support the use of force.$^{56}$ In addition, these officials established a new group within the Pentagon to review intelligence data and produce and provide to the President "alternative intelligence assessments" emphasizing the Iraq threat. ${ }^{57}$ Two bipartisan reports concluded

53. Paul R. Pillar, Intelligence, Policy and the War in Iraq, FOREIGN AFFAIRS, Mar./Apr. 2006, at 15; see also MELVIN A. GOODMAN, FAILURE OF INTELLIGENCE 22552 (2008).

54. See George Tenet, At the Center of the Storm 361-63 (2007) (describing a December 2002 briefing with the President in which he presented evidence of Iraq's weapons' capacity: "At no time did [the President] or anyone else in the room suggest that we collect more intelligence to find out if the WMD were there or not."); see also S. REP. NO. 108-301, supra note 45, at 23 ("In each instance where the Committee found an analytic or collection failure, it resulted in part from a failure of Intelligence Community managers throughout their leadership chains to adequately supervise the work of their analysts and collectors. They did not encourage analysts to challenge their assumptions, fully consider alternative arguments, accurately characterize the intelligence reporting, or counsel analysts who lost their objectivity.").

55. S. REP. NO. 108-301, supra note 45 , at 15,20

56. See, e.g., SEYMOUR M. Hersh, CHAIn OF COMMAND: THE ROAD FROM 9/11 TO ABU GHRAIB 228 (2004) ("Senior C.I.A. analysts dealing with Iraq were constantly being urged by the Vice President's office to provide worst-case assessments on Iraqi weapons issues.").

57. See DEPARTMENT OF DEFENSE OFFICE OF INSPECTOR GENERAL, REVIEW OF PRE-IRAQI WAR ACTIVITIES OF THE OFFICE OF THE UNDER SECRETARY OF DEFENSE FOR POLICY 2 (2007), available at http://ftp.fas.org/irp/agency/dod/ig020907.pdf ("[T]he actions were ... inappropriate given that the intelligence assessments were intelligence products and did not clearly show the variance with the consensus of the Intelligence Community."). 
that the intelligence analysts were not pressured by Administration officials to conform their conclusions to fit the war policy. ${ }^{58}$ Others have observed, however, that more subtle influences, that are more difficult to measure, likely conformed intelligence information and conclusions to support administration policy, ${ }^{59}$ and some agencies, at least, have bureaucratic incentives to advocate that threats exist. ${ }^{60}$

Incomplete Oversight of the Accuracy of Fact Claims. Selective presentation of facts by executive department advocates for the purpose of persuading Congress and the public to consent to policy occurs with respect to any decision framed for debate. With respect to most issues, however, executive department officials present their facts subject to motivated and aggressive oversight. Members of Congress, particularly of the opposite political party, journalists and media commentators, and private interest groups and entities usually have the incentive and ability to check the fact claims that executive branch officials assert in support of policy. The executive branch information control described above impacts the ability of all of these sources to engage in effective oversight of threat claims. But access is not the only barrier to effective oversight. Incentives, too, may be skewed when the President makes threat claims to persuade Congress and the public to consent to the use of force, and appear to have been skewed in the lead-up to the Iraq War.

On paper, and written into the Constitution specifically, Congress has special authority to cut through executive branch secrecy to oversee the fact claims made to persuade it and the

58. S. REP. NO. 108-301(2004) supra note 45, at 357; THE COMMISSION ON THE INTELLIGENCE CAPABILITIES OF THE UNITED STATES REGARDING WEAPONS OF MASS DESTRUCTION, REPORT TO THE PRESIDENT OF UNITED STATES 11 (2005), available at http://www.gpoaccess.gov/wmd/pdf/full_wmd_report.pdf.

59. See Joseph Cirincione et al., supra note 34, at 51 (it "strains credulity" to believe that the environment created by Bush Administration activities did not cause intelligence analysts to feel pressure to produce threat information); Warren P. Strobel, Some in Bush Administration Have Misgivings About Iraq Policy, MCClATCHY, Oct. 7, 2002, http://www.mcclatchydc.com/128/story/8592.html (multiple intelligence analyst sources felt "under intense pressure to produce reports supporting the White House's argument[s]"); see also Paul R. Pillar, supra note 53 (listing multiple ways more subtle than arm twisting by which intelligence was politicized in the lead up to the Iraq War); Cavanaugh, supra note 21, at 567 ("The Department of State and the CIA may be less inclined to present hawkish information [than the Department of Defense], but their institutional relationship with the president and Congress and their small size give them few resources with which to sustain opposition.").

60. Cavanaugh, supra note 21, at 567 ("Since perception of threat is correlated with department budgets, prestige, and opportunities in the private sector, many bureaucrats have incentives to cooperate [with executive department threat inflation] in order to advance either department or personal interests."). 
public to consent to the use of force. ${ }^{61}$ With respect to the facts that form the basis of executive department advocacy, Congress has the power to oversee the intelligence collection and analysis processes, to require evidence and testimony from intelligence officials to explain the meaning of information gathered and the conclusions reached, and to review highly secret raw information that relates to its oversight responsibilities. ${ }^{62}$ Practical obstacles exist to Congress achieving parity with the executive branch in obtaining, understanding and reaching judgments about intelligence information that bears on threat assessments. ${ }^{63}$ Still, Congress's oversight efforts routinely fall short of what it could practically achieve. ${ }^{64}$ Critiques of Congress's failure to exercise the authority that it has to engage in effective ongoing intelligence agency oversight, and to diligently exercise its authority to consent to and oversee the use of force, abound. ${ }^{65}$ Reasons that explain this pattern of neglect by Congress help to explain why it failed to effectively fact check executive department threat claims with respect to Iraq. These include the complexity and work load of intelligence oversight, the President's superior access to intelligence information and expert analysis, and the lack of public visibility of the work. ${ }^{66}$ Observers note that the rise of partisanship and the decline of individual work ethics lower

61. US CONST. art. I, $\S 8$, cl. 11 (Congress has the power to declare war); Louis Fisher, Congressional Access to National Security Information, 45 HARV. J. ON LEGIS. 219 (2008).

62. S. REP. NO. 108-301, supra note 32, at 7 ("The vast majority of intelligence products are available to Congress."); CRS, CONGRESS AS A CONSUMER OF INTELLIGENCE INFORMATION (2009) (Congress routinely has access to finished intelligence products and information provided in briefings; although it does not have routine access to raw intelligence, it has obtained it upon request).

63. See Loch K. Johnson, Governing in the Absence of Angels 16-19 (May 9, 2003), available at http://www.wilsoncenter.org/events/docs/johnson.doc (unpublished paper presented to the Wilson Center Congress Project) ("Lawmakers now have, in theory at least, access to all information that the secret agencies provide to the executive branch, with the exception of the President's Daily Brief. In reality, Congress frequently has to throw a fit before the agencies are responsive.").

64. Anne Joseph O'Connell, The Architecture of Smart Intelligence: Structuring and Overseeing Agencies in the Post-9/11 World, 94 CAL. L. REV. 1655, 1671-73 (2006).

65. See, e.g., Denis McDonough et al., No Mere Oversight, CTR. FOR AM. PROGRESS, June 13, 2006, http://www.americanprogress.org/issues/2006/06/ b1761097.html; Dahlia Lithwick, Wrestling Over War Powers, NEWswEEK, July 21, 2008 , at 18, available at http://www.newsweek.com/id/145866 (observing that, with respect to war powers, many view Congress as a "constitutional bathmat").

66. O'Connell, supra note 64, at 1660-63; McDonough et al., supra note 65, at 2728; Tim Poemer, Watching the Watchers: The Challenge of Intelligence Oversight, CTR. FOR NATIONAL POLICY, June 1, 2007. 
the incentives of members to work hard and in a bipartisan way to oversee executive action regardless of party alignment. ${ }^{67}$

In addition to these incentives generally, the Iraq experience reveals that the process of executive department decision making and advocacy can impact the incentives and practical abilities of Congress members to fact check administration threat claims. It is not clear exactly when the President made the decision to use force against Iraq ${ }^{68}$ What is clear is that the question was not framed for decision by Congress until late summer $2002 .^{69}$ By that time, the Administration had made its decision, lined up England as an ally, and planned and begun implementing a comprehensive strategic marketing campaign to persuade Congress members and the public to consent to the use of force. ${ }^{70}$ The President pressed Congress members to deliberate and decide quickly, during the two months between their return from summer recess and their break for the mid-term elections. ${ }^{71}$ During this time, executive branch officials engaged in an aggressive and targeted communications campaign aimed at convincing Congress members, and particularly key opinion leaders in both parties, that the threat claims were true. ${ }^{72}$ These efforts

67. See, e.g., ThOMAS E. MANn AND NORMAn J. ORSTEIn, THE BROKEN BrancH (2006) (noting the rise of partisanship and the "Tuesday to Thursday" schedule generally).

68. John J. Mearsheimer \& Stephen M. Walt, Op-Ed., Keeping Saddam Hussein in a Box, N.Y. TIMES, Feb. 2, 2003, at 4-15, available at http://www.nytimes. com/2003/02/02/opinion/02MEAR.html?scp=1\&sq=Mearsheimer\%20Feb. \%202,\%20200 $3 \&$ st=cse; Memorandum from Matthew Rycroft to David Manning (July 23, 2002) (hereinafter Downing Street Memo), available at http://www.timesonline.co.uk/tol/ news/uk/article387374.ece.

69. The President initially claimed that he did not need Congress' consent to use force. Michael Powell, Appeals Court Weighs Bush's War Powers, WASH. POST, Mar. 12, 2003, at A14. In September of 2002, he changed his mind. Christopher Marquis, Threats and Responses: Congressional Memo, N.Y. Times, Sept. 26, 2002, at A17 (the White House submitted a resolution to Congress seeking approval for the use of "all means that [the President] determines to be appropriate, including force").

70. See Warren P. Strobel \& John Walcott, Bush Has Decided to Overthrow Hussein, MCClatchy Wash. Bureau, Feb. 13, 2002; Downing Street Memo, supra note 68 (about information to be fixed around WMD); Joseph Cirincione, Not One Claim was True, Bull. OF THE ATOMIC SCIENTISTS, Jan./Feb. 2005, at 65, 66 (reviewing JOHN PRADOS, HOODWINKED: THE DOCUMENTS THAT REVEAL HOW BUSH SOLD US A War (2004)) (the White House Information Group was set up by Chief of Staff Andrew H. Card and chaired by Karl Rove in August 2002 to coordinate the campaign to convince Americans to go to war in Iraq).

71. Press Release, Office of the Press Secretary, President Discusses Iraq, Domestic Agenda with Congressional Leaders (Sept. 18, 2002), available at http://georgewbushwhitehouse.archives.gov/news/releases/2002/09/print/20020918-1.html ("I want to thank the leadership for its commitment to get a resolution done before members go home for the election break.").

72. MiCHAEL ISIKOFF \& DAVID CORN, HubRis: THE INSIDE STORY OF SPIN, 
included a speech by the President before the United Nations General Assembly ${ }^{73}$ and to the Nation on the first anniversary of the September 11 terror attacks with a flood lighted Statue of Liberty as the backdrop, ${ }^{74}$ other public statements by other officials, ${ }^{75}$ documents detailing the threats, ${ }^{76}$ and classified hearings and briefings at which officials presented specific pieces of evidence as undisputed and proving that Iraq posed a real and immediate threat. ${ }^{77}$ These presentations were one-sided, in support of administration advocacy, and designed to reduce the incentives of Congress members to engage in extensive fact checking. ${ }^{78}$ The Administration delayed delivery of the most balanced information it presented to Congress, producing it only upon request by Senate committee members and not until three days before the vote. ${ }^{79}$ While the 92 page classified version was difficult for Congress members to access and understand, ${ }^{80}$ the short, unclassified summary, which did not contain the balanced information of the secret version, was freely available, to members, their

SCANDAL, AND THE SELLING OF THE WAR (2006).

73. President George W. Bush, Address to the United Nations (Sept. 12, 2002), available at http://transcripts.cnn.com/2002/US/09/12/bush.transcript/.

74. President George W. Bush. Address on Sept. 11, 2002 (Sept. 11, 2002), available at http://archives.cnn.com/2002/US/09/11/ar911.bush.speech.transcript/index.html.

75. See S. REP. NO. 110-345, supra note 1 (outlining many statements by Bush officials that were later proven to be false).

76. See, e.g., A DECADE OF DECEPTION AND DEFIANCE; SADDAM Hussein's DEFIANCE OF THE UNITED NATIONS (2002) (this served as President Bush's background paper for his September 12th speech to the United Nations General Assembly).

77. See ISIKOFF \& CORN, supra note 72, at 124-26 (describing briefings).

78. In a statement several months later, the President's press secretary captured the gist of the mindset that the executive branch sought to instill through its advocacy efforts: "The president of the United States and the secretary of defense would not assert as plainly and bluntly as they have that Iraq has weapons of mass destruction if it was not true, and if they did not have a solid basis for saying it." David E. Sanger, Threats and Responses: Inspections; U.S. Tells Iraq It Must Reveal Weapons Sites, N.Y. TIMES, Dec. 6, 2002, at A1 (quoting White House Press Secretary Ari Fleischer).

79. The October 2002 National Intelligence Estimate (NIE) titled "Iraq's Continuing Programs of Weapons of Mass Destruction," was produced in a rapid timeframe at the request of the Senate Committee on Intelligence. See S REP. NO. 108-301, supra note 45 , at 12-14 (describing requests by multiple members of the committee). An NIE is "an appraisal of a foreign country or international situation . . . reflecting the coordinated judgment of the entire intelligence community." Loch K. Johnson, An Appraisal of the National Intelligence Estimate (NIE) 1950-2005 6 (Mar. 26, 2008) (unpublished paper presented at the 49th Annual Convention of the International Studies Association). Neither the Director of Central Intelligence nor any executive official had requested that one be produced prior to seeking congressional authorization to use force in Iraq.

80. Three days before the votes in Congress occurred, the classified NIE was made available to members of Congress in a secured location. Members were required to sign for access to the document. They could not take staff with them into the secure room, they could not remove the document from the room, and they could not take notes. Records indicate that very few members of Congress viewed the full document. Priest, supra note 40 . 
staff, the media and the public. ${ }^{81}$ Although the public document was accessible, its release so close in time to the votes in Congress diminished the ability of members of the media or private entities to analyze the advocacy piece, identify its weaknesses and publicize them in a way that could increase the incentives of Congress members to look more critically at the evidence presented by the Administration. Although not insurmountable, this sequence of rushed congressional fact finding and decision making after the President had already made his decision and planned and embarked on his persuasive advocacy campaign presented an obstacle that reduced both the incentives and practical abilities of Congress members to fact check executive department threat claims.

Partisan and electoral considerations can usually be expected to motivate members of the opposite party to resist aggressive executive department advocacy, and to take the time and engage in the effort required to check and contest the facts the President asserts in support of policy. But when those facts support threat claims in support of the use of force, experience indicates that these incentives may operate differently. For a number of reasons, threat claims are easier to make than they are to oppose..$^{82}$ Voters reward leaders who make threat claims and carry through with a successful use of force ${ }^{83}$ Politicians who question threat claims and prevent the use of force do not generally receive the same magnitude of electoral reward ${ }^{84}$ In fact, politicians perceive that voters punish those who oppose a use of force that turns out to be successful. ${ }^{85}$ These political incentives specific to threat claims likely contributed to the decisions of a number of Congress members not to examine the evidence presented by Bush Administration officials more aggressively, to

81. Senate Committee on Intelligence, Prewar Intelligence ASSESSMENTS OF POST-WAR IRAQ, S. REP. NO. 108-301, supra note 45, at 295 ("The intelligence community's elimination of the caveats from the unclassified white paper misrepresented their judgments to the public, which did not have access to the classified National Intelligence Estimate containing the more carefully worded assessments.").

82. See generally notes 23-25 supra.

83. See, e.g., Terrence L. Chapman \& Dan Reiter, The United Nations Security Council and the Rally 'Round the Flag Effect, 48 J. CONFLICT RESOLUTION 886, 886 (2004).

84. See Miroslav Nincic, Democracy AND Foreign Policy 118 (1992) ("[T]he electoral punishment for a mistaken underestimate of the Soviet challenge . . has typically been greater than the punishment associated with a misguided overestimate of the threat.").

85. See James L. Regens et al., The Electoral Consequences of Voting to Declare War, 39 J. CONFLICT RESOLUTION 168 (1995). 
acquiesce to the short time period for congressional decision making, and to vote to authorize the use of force. ${ }^{86}$

While the electoral incentives likely had real effects on the behavior of Congress members, the reality of the perceptions on which they were based is less certain. A troubling possibility is that the legislators' deference because of their projection of voters' support for the use of force may in fact have helped to form it. That is, Congress members who thought the public would react negatively if they questioned the Administration's pro-war advocacy, and in particular the fact claims upon which the assertions of grave and immediate threat were based, may have read the public wrong, or at least too strongly. ${ }^{87}$ Debate within Congress or among members of Congress and the executive branch is crucial to identifying the issues and establishing credible, expert assessments of the facts upon which the public's opinion formation about policy depends. ${ }^{88}$ Although at a practical disadvantage vis-à-vis the President, Congress has greater authority than any other potential source of oversight to access and examine the evidence presented by executive officials to support their threat claims. To the extent that Congress members fail to exercise their special oversight authority because they predict that voters will punish them for doing so, public opinion may "echo" their failure to engage in effective fact checking rather than demonstrate that they would have been punished if they did. Additionally, by approving a resolution authorizing the use of force without the need of a further vote by Congress, that body effectively truncated its own debate. While Congress members could express opinions between their October 2002 vote and the March 2003 use of force, they would carry much less weight, in the media and in the public's opinion formation, than the President's advocacy, because the decision in Congress

86. See Elizabeth Drew, War Games in the Senate, N.Y. REV. OF BOOKS, Dec. 5, 2002, available at http:/www.nybooks.com/articles/archives/2002/dec/05/war-games-inthe-senate/; Louis Fisher, Deciding on War Against Iraq: Institutional Failures, 118 POL. SCI. Q. 389 (2003).

87. See Frank Rich, The Greatest StORy EVEr SOld 63 (2006) ("The polls, far from rationalizing the Democrats' timidity, suggested that they might have won a real debate had they staged one."); Fisher, supra note 86, at 403 ("Why were Democrats so anxious about being seen as antiwar? There was no evidence that the public in any broad sense supported immediate war against Iraq.").

88. As to "elite discourse" generally, see Zaller, supra note 38, discussing media coverage. As to partisan cues, see Adam Berinsky, Assuming the Costs of War: Events, Elites, and American Public Support for Military Conflict, 69 J. OF POL. 975, 978 (2007), available at http://web.mit.edu/berinsky/www/war.pdf ( "[P] atterns of elite discourse - the stated positions of leading Democratic and Republican politicians - will play a large role in determining public support for war.”). 
was over, and the perception and reality was that the war decision was the President's to make.

The media is another potential source of oversight. Although members of the media have no legal right to access and evaluate classified intelligence information that is superior to the public, they have much greater practical access to information and experts whose evaluations bear on threat assessments, and they have professional responsibility to fact check government advocacy. ${ }^{89}$ Despite their access and public responsibilities, most media entities did not effectively fact check the Bush Administration's threat claims before the use of force. ${ }^{90}$ The generally pro-war media coverage had a number of particular aspects. One was that the media reflected or embraced the patriotism that threat claims typically invoke. ${ }^{11}$ Another was that reporters included information and advocacy volunteered by top executive branch officials, rather than digging for information or opinions offered by sources outside the Administration or by lower level employees. ${ }^{92}$ Reporting and commentary questioning the suffi-

89. See Marianne M. Jennings, Where Are Our Minds and What Are We Thinking? Virtue Ethics for a "Perfidious" Media, 19 Notre DAme J.L. ETHICS \& PUB. POL'Y 637, 653-72 (2005) (outlining scandals at major newspapers and television stations where journalists have failed to fact check information they disseminated to the public).

90. Michael Massing, supra note 51; Buying the War (PBS television broadcast Ap25, 2007), available at http://www.pbs.org/moyers/journal/btw/transcript1.html ("I went back and did the math. From August 2002 until the war was launched in March of 2003 there were about 140 front page pieces in The Washington Post making the Administration's case for war. . . . But there was only a handful . . . of [opposition] stories that ran on the front page." (quoting Howard Kuntz, Washington Post media critic)); Editorial, The Times and Iraq, N.Y. TIMES, May 26, 2004, at A1, available at http://www.nytimes. com/2004/05/26/international/middleeast/26FTE_NOTE.html?pagewanted=1. ("[W]e have found a number of instances of coverage that was not as rigorous as it should have been. In some cases, information that was controversial then, and seems questionable now, was insufficiently qualified or allowed to stand unchallenged. Looking back, we wish we had been more aggressive in re-examining the claims as new evidence emerged-or failed to emerge."); Lorie Conway, Iraq War Documentaries Fill a Press Vacuum, NIEMAN REPS., Spring 2005, http://www.nieman.harvard.edu/reportsitem. aspx?id=101078 ("[T]hree network news presidents agreed that their news coverage should have more aggressively challenged the Bush administration's reasons for going to war.").

91. Some broadcast newscasters and commentators openly announced a duty to be patriotic in their coverage. David Folkenflik, Fox News Defends its Patriotic Coverage, BALTIMORE SUN, Apr. 2, 2003, at 1D. Others tailored their coverage this way to meet what they perceived to be their viewers' preferences. CNN produced different versions of its war news for its United States and foreign audiences. Kaufmann, supra note 20, at 45 (noting that CNN issued a "cheerleading" version of Iraq War coverage for U.S. audiences and that partisan news organizations will deliver the ideological slant their audiences want).

92. A study of broadcast news prior to the Iraq War indicates that it quoted executive department sources twice as much as any other source, and that these sources were, predictably, disproportionately in favor of the use of force. See Matthew Guardino \& 
ciency and credibility of the evidence that the Administration presented to support its threat claims did in fact exist, both before Congress voted to authorize the use of force and, in greater volume, before the war began. ${ }^{93}$ Nevertheless, reporting that generated misperceptions about the Iraq threat predominated in broadcast news ${ }^{94}$ and on the pages of opinion leading print publications as well. ${ }^{95}$ Incentives by media sources and individual reporters to get big scoops and publish high profile stories help explain why selected pieces of raw intelligence information that supported threat claims received prominent and uncritical coverage. ${ }^{96}$ A critique of media coverage of Secretary of State Colin Powell's presentation to the United Nations Security Council pointed out that media reports frequently presented unverified

Danny Hayes, Whose Views Made the News? (Apr. 3, 2008), available at http://www.allacademic.com/meta/p_mla_apa_research_citation/2/6/6/6/4/p266648_index. html (unpublished paper presented at the 2008 annual meeting of the Midwest Political Science Association).

93. Much information exposing the weakness of the administration's evidence or conflicting with its threat claims was available to the few journalists who actively pursued it. Knight Ridder reporters published a series of articles carefully examining the executive department's threat claims. See generally Noteworthy Stories, http://www.mcclatchydc.com/128/. One, in particular, compared a series of official statements with available evidence and the judgments of unnamed officials. Warren P. Strobel, supra note 5960. This piece exposes most of the weaknesses in the threat claims, noting, however, that "[n]one of the dissenting officials, who work in a number of different agencies, would agree to speak publicly, out of fear of retribution." Id.; Johanna McGeary et al., What does Saddam Have?, TIME ON CNN, Sept. 16, 2002, http://www.time.com/time/magazine/article/0,9171,1003240,00.html; McGovern, supra note 22 .

94. Kull, supra note 31.

95. See Posting of Max Fullmer to The Huffington Post, http://www.huffingtonpost. com/2008/03/17/the-reporting-team-that-g_n_91981.html (Mar. 17, 2008 18:29) ("In the months before the U.S. invasion of Iraq, the reporters in the Knight Ridder Newspapers Washington D.C. bureau were virtually alone in their questioning of the Bush Administration's allegations of links between Saddam Hussein, weapons of mass destruction and international terrorism."); Buying the War, supra note 90 ("We were under the radar most of the time. . . . We're less influential [than the New York Times or Washington Post, even though they potentially have more readers]." (quoting John Walcott, one of the Knight Ridder reporters)).

96. The New York Times in particular ran several front page stories during the crucial stages of congressional and public opinion formation, which repeated and gave credibility to details used by the administration to argue that Iraq posed an immediate threat. See Franklin Foer, The Source of the Trouble, N.Y. TiMES MAG., May 21, 2005, available at http://nymag.com/nymetro/news/media/features/9226/ (describing how Judith Miller, a star New York Times reporter, became close to Ahmad Chalabi, the Iraq defector, and administration sources, and created numerous high profile stories that promoted the administration's case for war). Judith Miller has since left the New York Times, and in 2008 became a contributor to FOX News. Paul J. Gough, Veteran Reporter Judith Miller Joins Fox News, REUTERS, Oct. 20, 2008, http://www.reuters.com/article/idUSTRE49J80G20081020. 
allegations as facts, rather than qualifying them as being assertions in support of advocacy. ${ }^{97}$

Additionally, the decisions of Congress members not to exercise their authority to fact check administration threat claims, through inquiry and public debate, contributed to the lack of critical examination of those claims in the media. As noted above, Congress members have the constitutional authority to access and examine most of the information that bears upon threat assessment, and to publicize much of it. At least, they can express judgments about its sufficiency and credibility, which can challenge the authority with which executive officials present the threat claims, and so present the type of "debate" about an "issue" that reporters are trained to present. That is, debate and decision frame a newsworthy "story," and so, as congressional inquiry into the Administration's claims "melted away," reporters had to turn to less credible sources to balance coverage of administration threat claims and war advocacy. ${ }^{98}$ Scholars have reflected upon the challenge that this lack of debate among credible authority figures posed to public opinion formation with respect to the Iraq War, since theory proposes that the public particularly needs educated experts and partisan cues to filter information with respect to foreign affairs. ${ }^{99}$ More than one ob-

97. Press Release, Fairness \& Accuracy in Reporting, A Failure of Skepticism in Powell Coverage (Feb. 10, 2003), available at http://www.fair.org/press-releases/unpowell-iraq.html ("Reporters at several major outlets neglected to observe the journalistic rule of prefacing unverified assertions with words like "claimed' or 'alleged."').

98. Stanley Feldman et al., Going to War: When Citizens Matter 7 (Apr. 3, 2008), available at http://www.allacademic.com/meta/p_mla_apa_research_citation/2/6/6/5/2/ p266525_index.html (unpublished paper presented at the annual meeting of the Midwest Political Science Association). See Guardino \& Hayes, supra note 92, at 15-19 (in the absence of domestic authorities offering anti-war critiques, journalists turned to foreign sources, including Iraqi officials and citizens, as sources to balance their coverage of views, even though these views were likely to be accorded less weight than credible domestic sources by American viewers).

99. Feldman, supra note 98 , at 4 ("[F]oreign affairs provide an especially tough test of citizens' ability to arrive at reasoned judgment independently of the influence of political elites. .. . The existence of disagreement among major political players is critical to balanced coverage of foreign affairs and domestic issues because of the media's tendency to attend most closely to the views of influential policy makers."); William G. Howell \& Jon C. Pevehouse, When Congress Stops Wars, FOREIGN AFFAIRS, Sept.-Oct., 2007, available at http://www.realclearpolitics.com/articles/2007/09/when_congress_stops_wars. html ("Many studies have shown that the media regularly follow official debates about war in Washington, adjusting their coverage to the scope of the discussion among the nation's political elite. And among the elite, members of Congress - through their own independent initiatives and through journalists' propensity to follow them-stand out as the single most potent source of dissent against the president. . . Whether the media scrutinize every aspect of a proposed military venture or assume a more relaxed posture depends in part on Congress' willingness to take on the president."). 
server has concluded that because the public did not have access to this debate through the media that the "marketplace of ideas," which is supposed to ensure consent to use of force decision making and in particular to limit the wars that democracies engage in, failed.

Finally, an important accountability check on executive advocacy with respect to domestic legislation is organized, affluent opposition. Private organizations spend money to influence legislators and communicate with the public to oppose administration advocacy. These private organizations employ lobbyists who become experts in the facts and law that impact their interests. While lobbyists of course seek to persuade Congress members to act to further the policy goals of the organization that funds them, the private resources devoted to the particular subject area mean that lobbyists can do the hard work of collecting, understanding, and communicating the meaning of complex information to very busy people for whom the issue is but one of many they must address. That private organizations wield campaign contributions and other support that may enhance legislators' electoral success can counter other incentives and spur Congress members to take action to challenge facts or policy advocated by the President.

Private organizations sporadically advertise and lobby Congress members against the use of force. ${ }^{101}$ However, there do not appear to be private, affluent organizations that employ lobbyists on a continuing basis to collect, understand and communicate the meaning of threat assessment information to Congress members and members of their staffs, or at least none with a financial incentive to question administration threat claims. ${ }^{102} \mathrm{Of}$

100. Kaufmann, supra note 20. See generally Cramer, supra note 22. See also A. Trevor Thrall, Framing Iraq: Threat Inflation in the Marketplace of Values, in AMERICAN FOREIGN POLICY AND THE POLITICS OF FEAR 174 passim (A. Trevor Thrall \& Jane K. Cramer eds., 2009) (observing that "the most popular line of argument is that Bush was able to induce a failure of the marketplace of ideas," but arguing that a "marketplace of values" is a better way to understand how policy making should function).

101. See, e.g., Michael Crowley, Can Lobbyists Stop the War?, N.Y. TIMES, Sept. 9, 2007, at 6-54 (describing Americans Against Escalation in Iraq, a coalition brought together by MoveOn.org to lobby Congress, noting that the group spent over $\$ 12$ million in 2007, and that its members are in frequent contact with the staffs of House and Senate majority leaders).

102. Military contractors can be expected to favor the use of force generally. Oil companies can be expected to favor wars that make access to their product easier. Anotonia Juhasz, Big Oil's Last Stand, FOREIGN POL'Y IN FOCUS, Oct. 22, 2008, http://www.fpif.org/articles/big_oils_last_stand (Big Oil spends tens of thousands of dollars every year on lobbying the federal government, which is much less than the money it spends on elections. "Oil Change International compiled voting records for the five most 
course, the lobbyists would not have the ability to access secret information to engage in ongoing threat assessment and education for Congress members. Motivated lobbyists would, however, have the ability to prod Congress members and members of their staffs to demand and obtain threat assessment information on an ongoing basis. Although they could not review the contents, they could motivate the process, inquiring about briefings and publicizing that they happened, and providing the questions to ask.

With respect to the Iraq War then, it is no surprise that there appears to have been no organized, well funded private organization that employed lobbyists that helped Congress members and their staffs do the work of fact checking administration threat claims before Congress voted to authorize the use of force. ${ }^{103}$ Some fact checking was done by private entities and individuals. Research organizations produced some commentary and reports that analyzed the evidence offered by the Administration in support of its claims. ${ }^{104}$ And, prominent individuals with expertise and credibility, including officials associated with the first Bush Administration, pointed out the dearth of hard evidence offered by the Administration to support its threat claims and questioned the reasons offered for the use of force more generally. ${ }^{105}$

important bills on the Iraq War: the initial 2003 vote authorizing the use of force in Iraq and the subsequent supplemental war finding bills in 2003, 2004, 2005, and 2006. From 1989 to 2006, members of Congress who voted for all five bills received on average eight times more money from the oil and gas industry ... than those who voted against the war.").

103. Opposition became more organized as the war progressed. A number of groups funded advertisements against the 2007 troop surge. See, e.g., Ryan Grim, MoveOn Already Attacking Senators Blocking Debate on Surge, Politico, Feb. 6, 2007, http://www.politico.com/news/stories/0207/2659.html.

104. See, e.g., INTERNATIONAL INSTITUTE FOR STRATEGIC STUDIES, IRAQ'S WEAPONS OF MASS DESTRUCTION: A NET ASSESSMENT (2002).

105. See, e.g., Peggy Noonan, Time to Put the Emotions Aside, Wall STREet J., Sept. 11, 2002, at A14 available at http://www.opinionjournal.com/columnists/pnoonan/ ?id=110002249 (former speech writer to the first President Bush, asking for "hard data that demonstrate conclusively that Saddam has weapons of mass destruction which he is readying to use on the people of the U.S. or the people of the West"); see also Brent Scowcroft, Don't Attack Saddam, WALl Street J., Aug. 15, 2002, at A12, available at http://www.opinionjournal.com/editorial/feature.html?id=110002133; James A. Baker, The Right Way to Change a Regime, N.Y. TIMES, Aug. 25, 2002, at 4-9, available at http://www.nytimes.com/2002/08/25/opinion/25BAKE.html (former secretary of state James Baker warns that the United States should not attack Iraq alone); Mearsheimer \& Walt, supra note 68; IN SHIFTING SANDS (Five Rivers 2000) (Scott Ritter documentary about the lack of weapons of mass destruction in Iraq). 
In sum, both lack of access to intelligence information and disincentives by the surrogates upon whom the public relies to access and assess complex information that bears on policy decisions to inquire more thoroughly into executive department threat claims led to incomplete oversight of the accuracy of the fact claims that formed the core of the executive department's use of force advocacy.

\section{USE OF FORCE ADVOCACY, THREAT CLAIMS AND THE QUESTION OF CONTEMPORANEOUS ACCOUNTABILITY DURING THE FIRST YEAR OF THE OBAMA PRESIDENCY}

Although he inherited the conflict, Barack Obama is a war president, actively engaged in assessing threats, and in deciding upon and advocating for the use of force to address them. The use of force in Afghanistan, against the Taliban, which aided alQaeda, which planned and committed the September 11, 2001 attacks, has bled into Pakistan, ${ }^{106}$ and is likely seeping into other regions as well. ${ }^{107}$ The troop commitment in Afghanistan has risen significantly twice during the first year of the Obama presidency. ${ }^{108}$ In September 2009, the President began a severalmonth deliberation process, which culminated in a decision to increase troop strength in Afghanistan substantially. Immediately upon announcing the content of his decision, the President ordered its implementation. Both he and other executive department officials have made threat claims as part of a strategic and coordinated communications campaign to persuade Congress and the nation to consent to his chosen policy. Additionally, during this same time period, other threats emerged. Attacks against United States targets - some aborted and some successful-unleashed a storm of inquiry into the accountability of this Administration for its threat assessments. ${ }^{109}$ Although the com-

106. Peter Baker, Obama's War over Terror, N.Y. TIMES MAG., Jan. 4, 2010, http://www.nytimes.com/2010/01/17/magazine/17Terror-t.html (over 50 drone strikes launched in 2009); Scott Shane \& Eric Schmitt, C.I.A. Deaths Prompt Surge in Drone War, N.Y. TIMES, Jan. 23, 2010, at A1, available at http://www.nytimes. com/2010/01/23/world/asia/23drone.html (over ten drone strikes in one month kill 90 people in Pakistan).

107. Michelle Levi, Roundtable Looks at Yemen Terror Threat, CBS NEwS, Jan. 3, 2010, http://www.cbsnews.com/stories/2010/01/03/ftn/main6049967.shtml.

108. See Barbara Starr, Obama Approves Afghanistan Troop Increase, CNN, Feb. 18, 2009, http://www.cnn.com/2009/POLITICS/02/17/obama.troops/index.html; see also Eric Schmitt, Obama Gives Troop Orders Before Speech, N.Y. TIMES, Dec. 1, 2009, at A1, available at http://www.nytimes.com/2009/12/01/world/asia/01orders.html.

109. See Borzou Daragahi \& Greg Miller, U.S. Casts Doubt on Bin Laden Claim, 
parison between the use of force decision making and threat claims made in support of policy of this President as compared to the last one must be imperfect, ${ }^{110}$ some insights can be drawn as to whether the structures, incentives and behaviors that impaired effective oversight have, or have not changed, with a new Oval Office occupant, a new Congress, and members of the media ostensibly committed to covering executive department threat claims less credulously.

Aggressive and Persuasive Use of Threat Claims in Support of the Use of Force. The Obama Administration has assembled and operates a formidable advocacy machine, which it deploys strategically and persistently to build support for the President's policies. ${ }^{111}$ The Administration uses multiple media and different forms of messages and appearances to find his audience and make his case. ${ }^{112}$ The more traditional forms of communication include print interviews, broadcast media appearances, press re-

L.A. TIMES, Jan. 25, 2010, at 13 , available at http:/articles.latimes. com/2010/jan/25/world/la-fg-bin-laden25-2010jan25 (detailing the failed attempt to blow up an American commercial jet for which al-Qaeda took credit); see also Posting of Jeff Zeleny to The Caucus: The Politics and Government Blog of The Times, http://thecaucus.blogs.nytimes.com/2010/02/05/obama-pays-tribute-to-fallen-cia-officers/ (Feb. 5, 2010 16:43 EST) (seven CIA officers were killed in Afghanistan in a suicide bombing); Ashley Powers, A Story of Shock, Chaos and Bravery Unfolds, L.A. TimES, Nov. 7, 2009, at A1 (attack on Fort Hood); A.G. Sulzberger \& William K. Rashbaum, Guilty Plea Made in Plot to Bomb New York Subway, N.Y. Times, Feb. 23, 2010, at A1 (guilty plea in plot to bomb New York subway).

110. The Iraq War decision required a vote by Congress to authorize it. U.S. CONST. art. I, § 8 ("The Congress shall have Power ... To declare War."). The decision to increase troop levels in an ongoing war does not clearly require a vote. But see Bruce Ackerman \& Oona Hathaway, What Will Congress Do About Afghanistan?, SLATE, Dec. 9, 2009 (arguing that Congress "should repeal the open-ended 2001 resolution and authorize Obama's 18-month surge through a new mechanism for ensuring the ongoing democratic legitimacy of limited wars"); David Rogers, Anti-War Lawmakers Want a Vote, POLITICO, Dec. 1, 2009, http://www.politico.com/news/stories/1209/30087.html ("Anti-war lawmakers in Congress are pressing for an early vote on funding for new troops in Afghanistan so that President Barack Obama's policy can be tested before thousands of additional Marines and soldiers are sent into combat.").

111. See Ken Auletta, Non-Stop News, New Yorker, Jan. 25, 2010, at 38-47 (describing the Obama communications operation and noting specifically that "[t]his White House, like others, does its best to manipulate press coverage"); K. Daniel Glover, The Cost of Controlling the Press, ACCURACY IN MEDIA, July 7, 2009, http://www. aim.org/aim-column/the-cost-of-controlling-the-press/ ("Overall, Obama is spending about 12 percent more for his communications operation than Bush $-\$ 4.97$ million compared with $\$ 4.44$ million.”); Jennifer Senior, The Message is the Message, N.Y. TIMES MAG., Aug. 2, 2009, http://nymag.com/news/politics/58199 (the Obama Administration's communications operation is "very disciplined" and "highly selective about access").

112. John T. Woolley \& Gerhard Peters, What About the Next 100? Obama in Action-Part VII: The 100th Day, AM. PRESIDENCY PROJECT, Apr. 30, 2009, http://www.presidency.ucsb.edu/obama_in_action_viii_043009.php ("Obama's Strategy of Persuasion ... He has used the unilateral powers of the presidency more vigorously than any of his predecessors."). 
leases and the President's weekly address carried via radio and the web. ${ }^{113}$ The Administration also makes use of technologies that bypass traditional media to communicate with the public directly, such as web pages devoted to promoting its policies, ${ }^{114} \mathrm{a}$ Flickr stream on which it publishes photographs, ${ }^{115}$ YouTube releases of interviews and speeches, ${ }^{116}$ and Twitter posts of excerpts. ${ }^{117}$ In addition to putting out a message, the executive branch employs means to search out and quickly counter information that undercuts its policies. ${ }^{118}$ The President's chief of staff holds a daily conference call with political analysts who regularly offer "independent" media commentary. ${ }^{119}$ An end-of-the-year review caused the Obama Administration to retool its communications strategy in light of lessons learned during the President's first twelve months in office. The honed strategy will emphasize "disciplined messaging," in which "unhelpful themes [are] filtered out in favor of topics that advance[] the [President's] goals," "quicker, more aggressive response to GOP attacks on the president and his policies,"

113. Thomas E. Mann, From Campaigning to Governing: Politics and Policymaking in the New Obama Administration, BROOKINGS INST., Apr. 21, 2009, http://www.brookings.edu/speeches/2009/0421_governance_mann.aspx ("Obama has chosen to err on the side of overexposure. Hardly a day goes by without his public presence, including speeches, press conferences, and meetings with members of Congress, CEOs, policy experts and ordinary citizens; exclusive interviews with network anchors and the national press; new access to minority media and sympathetic bloggers; an appearance on Jay Leno and a return to 60 Minutes; weekly trips around the country, with extensive news coverage.").

114. See The White House Briefing Room, http://www.whitehouse.gov/briefingroom. The President also has a Facebook page and blog.

115. Stan Schroeder, Obama On Flickr: The First 100 Days and More, MASHABLE, Apr. 29, 2009, http://mashable.com/2009/04/29/obama-flickr/ (photos depict Obama in a variety of situations: watching the Super Bowl in 3D, playing with a football in the Oval Office, or being briefed about the swine flu outbreak in the Situation Room).

116. See Brian Stelter, Obama to Field Questions Posted by YouTube Users, N.Y. TIMES, Feb. 2, 2010, at A10, available at http://www.nytimes.com/2010/02/01/us/politics/ 01youtube.html ("White House aides say the [YouTube] videos and webcasts are a powerful 'force multiplier' for the administration's persuasion efforts.").

117. Senior, supra note 111.

118. See Auletta, supra note 111, at 46 ("Reality Check" blog established by White House to challenge false assertions); Posting of Macon Phillips to The White House Blog, Facts are Stubborn Things, http://www.whitehouse.gov/blog/facts-are-stubbornthings (Aug. 4, 2009 06:55 EDT) (asking readers to pass along information if they "get an email or see something on the web about health insurance reform that seems fishy").

119. John F. Harris, Power, Politics, Gossip on Daily Call, Politico, Jan. 27, 2009, http://www.politico.com/news/stories/0109/18011.html.

120. Not surprisingly, some view the Obama administration's persuasive messaging techniques as heavy-handed. Reporters complain about press control, selective access, and staged "town hall" events. Senior, supra note 111 (quoting long-time White House correspondent Helen Thomas). The White House and FOX News have been at odds. White House Escalates War of Words With Fox News, Fox NEws, Oct. 12, 2009, 
out-of-Washington] backdrops" that were effective during the presidential campaign. ${ }^{121}$

The Obama Administration has used threat claims as a part of its strategic and coordinated communications campaign to build public support for his chosen policy to deploy additional troops in Afghanistan. The President's decision came after a three-month, highly publicized decision making process. Much anticipation and public conversation occurred during the President's deliberations, with widespread agreement that, once the decision was made, it would be his challenge to make his case and "sell" his chosen policy. ${ }^{122}$ Persuasive communications by executive branch officials have included formal speeches, ${ }^{123}$ Sunday talk show appearances ${ }^{124}$ congressional testimony ${ }^{125}$ direct media postings, ${ }^{126}$ and documents delivered to Congress and released publicly. ${ }^{127}$ In these communications, executive branch officials

http://www.foxnews.com/politics/2009/10/12/white-house-escalates-war-words-fox-news/ (on September 20, the President visited all major Sunday morning talk shows except the FOX Channel's. Anita Dunn, then communications director, called it "a wing of the Republican Party"); see also Brian Stelter, Fox's Volley With Obama Intensifying, N.Y. TIMES, Oct. 11, 2009, at B1, available at http://www.nytimes.com/2009/10/12/business/ media/12fox.html. Some fault the administration's transparency efforts, particularly the whitehouse.gov web page, as geared more toward "public persuasion than documentation." Mann, supra note 113.

121. Michael D. Shear, Better Focus, Faster Response Part of Obama Communications Plan, WASH. PosT, Feb. 15, 2010, at A06.

122. See David E. Sanger, Obama's Task: A Tough Sell on Friendly Territory, N.Y. TIMES, Sept. 23, 2009, available at http://www.nytimes.com/2009/09/23/world/23sanger. html; Obama Must Sell Afghan Surge, BREITBART, Dec. 16, 2009, http://www.breitbart. com/article.php?id=CNG.df1ebb0b552b58e02cf23ff8b0dba97a.9f1\&show_article=1 ("US President Barack Obama will have to sell his escalation of the war in Afghanistan to his divided Democratic allies in the US Congress, Democratic House Speaker Nancy Pelosi said.").

123. Brian Montopoli, Obama Lays Out New Afghanistan Strategy, CBS NEws, Dec. 1, 2009, http://www.cbsnews.com/stories/2009/12/01/politics/main5855734.shtml (speech from West Point announcing the troop increase); President Barack Obama, Remarks by the President at the Acceptance of the Nobel Peace Prize (Dec. 10, 2009), available at http://www.whitehouse.gov/the-press-office/remarks-president-acceptance-nobel-peaceprize.

124. Dianna Heitz, Sunday Talk Show Tip Sheet, POLITICO, Dec. 4, 2009, available at http://www.politico.com/news/stories/1209/30226.html ("Secretary of State Hillary Clinton and Defense Secretary Robert Gates headline this Sunday's television talk shows, as they continue to make the case for the administration's strategy to deploy 30,000 additional U.S. troops to Afghanistan and set a July 2011 deadline to begin a military withdrawal.").

125. E.g., Lynn Sweet, Hillary Rodham Clinton to Sell Obama Afghan Strategy to Congress, NATO, POL. DAILY, Dec. 1 2009, http://www.politicsdaily.com/2009/12/01/ hillary-rodham-clinton-to-sell-obama-afghan-strategy-to-congress/.

126. E.g., Posting of Jesse Lee to the White House Blog, The New Way ForwardThe President's Address, http://www.whitehouse.gov/blog/2009/12/01/new-way-forwardpresidents-address (Dec. 1, 2009 21:35 EDT).

127. See, e.g., Annual Threat Assessment of the U.S. Intelligence Community: Hearing 
have repeatedly asserted as true that the Taliban, which is located in Afghanistan where force is to be applied (1) is offering continuing support, including weapons, to al-Qaeda, which perpetrated the September 11, 2001 attacks; and that al-Qaeda (2) possesses the weapons capacity to pose an actual and immediate threat to the security of neighboring nations and the United States; (3) possesses the means of delivering the existing weapons into neighboring countries, including the United States; and (4) is inclined to attack other countries, including the United States. These types of threat claims have been broadcast and reported in various media. One example is President Obama's speech to the nation from the Military College at West Point announcing his decision to send additional troops to Afghanistan:

I do not make this decision lightly. I make this decision because I am convinced that our security is at stake in Afghanistan and Pakistan. This is the epicenter of violent extremism practiced by al Qaeda. It is from here that we were attacked on $9 / 11$, and it is from here that new attacks are being plotted as I speak. This is no idle danger; no hypothetical threat. In the last few months alone, we have apprehended extremists within our borders who were sent here from the border region of Afghanistan and Pakistan to commit new acts of terror....

And the stakes are even higher within a nuclear-armed Pakistan, because we know that al Qaeda and other extremists seek nuclear weapons, and we have every reason to believe that they would use them.

These facts compel us to act along with our friends and allies. ${ }^{128}$

Additionally, officials have offered pieces of vivid imagery to support their threat claims. ${ }^{129}$

With this advocacy, the Obama Administration presents facts about threats posed by the Taliban in Afghanistan and al-

Before H. Permanent Select Comm. on Intelligence, 111th Cong. 16-19 (2010) (statement of Dennis C. Blair, Director of National Intelligence) (assessing threat to national security posed by al-Qaeda and the Taliban in Afghanistan).

128. President Barack Obama, Remarks at the United States Military Academy at West Point, New York, 2009 DAILY COMP. PRES. DOC. 962 (Dec. 1, 2009), available at http://www.whitehouse.gov/the-press-office/remarks-president-address-nation-wayforward-afghanistan-and-pakistan.

129. Viola Gienger, Al-Qaeda Heads Terror 'Mafia' with Afghan Nexus, BLOOMBERG.COM, Dec. 3, 2009, http://www.bloomberg.com/apps/news?pid= 20601087\&sid=aqlbIZwRzjAM\&pos=9\# (quoting Secretary of State Hillary Rodham Clinton as describing "a syndicate of terrorism," in which, "[a]t the head of the table, like an old mafia diagram, sits al-Qaeda"). 
Qaeda for the purpose of influencing the public discussion and conclusions about the policy the President advocates and seeks the Nation to embrace. By presenting threats posed by the Taliban and al-Qaeda as actual, imminent, and potentially directed at the homeland, the President and his advisors argue that confronting the threat by use of force is a necessity, not a choice. ${ }^{130}$ To at least some extent, administration officials have attempted to present the justifications for war as simple and concrete, and in terms that invoked patriotism and emotions, all important elements to garnering public support for a costly foreign commitment.

The success of the Obama Administration's threat advocacy to build consent to the use of force is uncertain. Troops are being funded and deployed. Public opinion polls show varying support for the policy over time. ${ }^{131}$ These polls generally do not ask specifically whether members of the public believe the executive department's threat claims or correlate belief in the truth of the threat claims to support for the use of force. More certain than the impact of executive department threat advocacy on the opinion of Congress members and the public is that the Administration continues to communicate about threats and war events to build and maintain consent to its policies. ${ }^{132}$ That this Administration and every one that follows can be expected to advocate in this way means that it is of continuing relevance to compare the past to the present to identify whether change has happened to correct the structures, incentives and behaviors that allowed executive department officials to make threat claims without contemporaneous accountability.

Information Control in Support of Threat Claims. President Obama has superior legal or practical access to the intelligence information and opinions that formed the basis of his delibera-

130. See, e.g., Peter Baker \& Eric Schmitt, War Debate Now Leans to Focus on Al Qaeda, N.Y. TIMES, Oct. 8, 2009, at A1 ("Robert Gibbs, the White House press secretary, said ... that Mr. Obama's 'primary focus is on groups and their allies that can strike our homeland, strike our allies, or groups who would provide safe haven for those that wish to do that."').

131. See POLLINGREPORT.COM, http://www.pollingreport.com/afghan.htm.

132. See Sulzberger \& Rashbaum, supra note 109, at A1 (Attorney General Eric Holder described the threat as one of the most serious since 9/11: "This attempted attack on our homeland was real, it was in motion and it would have been deadly."); Greg Jaffe \& Craig Whitlock, Afghan City Now Is More than a Battle, WASH. PosT, Feb. 22, 2010, at A09 (Marjah chosen as site of major military offensive because it is a "symbol" that will help the U.S. and military "define [the] narrative," which will "convince Americans that a new era has arrived in the eight-year-long war and to show Afghans that U.S. forces and the Afghan government can protect them from the Taliban"). 
tions on the use of force and he has indicated that he intends to exercise that control to keep much of the information secret. In his multiple meetings he reviewed existing information and received expert interpretation and advice from his advisors and staff that is not available to Congress, the media or the public generally. He directed the creation of new information to aid his deliberations, and reacted strongly when information about the content of the deliberations leaked in what the Administration perceived to be attempts to influence the President's decision making. ${ }^{133}$ The President did not request that the intelligence agencies prepare a National Intelligence Estimate to aid his deliberations on the surge. ${ }^{134}$ It is not clear which, if any, of the "three dozen intelligence reports" and "thousands of pages of documents" ${ }^{135}$ he directed be prepared as part of the process have been released to Congress, or, in unclassified version, to the public. It is unclear the extent to which this Administration would resist explicit requests for information by Congress, should it make them. ${ }^{136}$

133. Peter Baker, Inside the Situation Room: How a War Plan Evolved, N.Y. TIMES, Dec. 6, 2009, at A1, available at http://www.nytimes.com/2009/12/06/world/asia/ 06reconstruct.html (noting that White House officials interpreted the leak of General McCrystal's report advising a troop increase as "an attempt to box in the president" and "were furious" when the general commented publicly that a plan less than the one he recommended would not work).

134. Melvin A. Goodman, Obama's Weak Report Card on the CIA, CONSTORTIUMNEwS.COM, (Nov. 30, 2009), http://www.consortiumnews.com/2009/ 113009a.html. The executive department delivers some threat assessment information to Congress on a yearly basis. The Director of National Intelligence (DNI) delivers an annual threat assessment to Congress. See Annual Threat Assessment of the U.S. Intelligence Community, supra note 127 (statement of Dennis C. Blair, Director of National Intelligence).

Additionally, each president periodically publishes a document titled National Security Strategy of the United States of America, which explains the outlines and objectives of all national security activities, including the use of force. See NATIONAL SECURITY STRATEGY (2010), available at, http://www.whitehouse.gov/sites/default/files/rss_viewer/ national_security_strategy.pdf.

135. See, e.g., Baker, supra note 133; Spencer Ackerman, Clinton Ties AfghanistanPakistan War to Domestic U.S. Threat, WASH. INDEP., Dec. 3, 2009, http://washingtonindependent.com/69533/clinton-ties-afghanistan-pakistan-war-todomestic-u-s-threat ("I am told by senior administration officials that the autumn Afghanistan-Pakistan strategy was informed by 30 intelligence products.").

136. See Walter Pincus, Renewed Veto Threat on Security Proposal, WAsH. Post, Mar. 16, 2010, at A04 ("The White House has renewed its threat to veto the fiscal 2010 intelligence authorization bill over a provision that would force the administration to widen the circle of lawmakers who are informed about covert operations and other sensitive activities."). The Obama administration's record on release of information is mixed. Compare Ed O'Keefe, FOIA-Request Audit Shows Limited Gains, WASH. POST, Mar. 15, 2010, at A04 (report by the National Security Archive at George Washington University indicates that during its first year, the Obama administration denied more Freedom of Information Act requests than the Bush administration); Garry Wills, Entangled Giant, 
This superior access to the entire body of intelligence information forms the implicit backdrop and grounding to the threat claims the President and others in his Administration make to persuade Congress and the public to consent to his policy choice. With respect to certain claims, executive branch officials rely on information that they do not reveal publicly to make their threat claims, suggesting that they have more and better quality supporting information than can be publicly revealed. ${ }^{137}$ They omit mention of dissent when presenting the Administration's chosen policy and facts supporting it. ${ }^{138}$ To some extent at least, executive department officials in their advocacy have asked the public to embrace the truth of threat claims based on trust rather than proof. It is difficult to gauge whether and to what extent Administration officials may be using their authority to classify and declassify information selectively for the purpose of influencing public debate in favor of their chosen policies. Allegations have been made that the Administration has released information that could have properly been classified for the purpose of supporting its policies. ${ }^{139}$ More difficult to assess is

N.Y. REV. OF BOOKS, Oct. 8, 2009, http://www.nybooks.com/articles/23110 (noting the administration's embrace of the "state secrets" privilege in litigation, its refusal to release photographs of "enhanced interrogation," and its objection to use of documents in litigation); with Associated Press, Agencies Ordered to Publish Data, N.Y. TIMES, Dec. 9, 2009, at A20, available at http://www.nytimes.com/2009/12/09/us/politics/09records.html ("The White House instructed every federal agency on Tuesday to choose at least three collections of previously undisclosed 'high value' government data and publish them on the Internet by the end of January, an ambitious order to make the administration as transparent as President Obama had promised it would be.").

137. See, e.g., Lolita C. Baldor, Al-Qaida Growing in Strength and Numbers in Africa, Associated PRESS, Mar. 1, 2010, reprinted in On The Defense Blog, http://onthedefense.wordpress.com/2010/03/01/recruiting-boom-aq-sees-major-gains-innorth-africa-causing-fissure-in-already-fragile-local-governments/ ("Al-Qaida's terror network in North Africa is growing more active and attracting new recruits, threatening to further destabilize the continent's already vulnerable Sahara region, according to U.S. defense and counterterrorism officials [who spoke on condition of anonymity].").

138. It is quite clear that the President was presented with information during his deliberations that conflicts with the decision he ultimately made. See Ken Dilanian, Black Eye for U.S. Embassy in Kabul, USA TODAY, Mar. 9, 2010, at 1A, available at http://www.usatoday.com/news/washington/2010-03-09-embassy_N.htm (leaked cable from U.S. Ambassador Karl Eikenberry questioning whether the military could meet its timeline to turn Afghanistan over to Afghan forces). Not surprisingly, this information does not form a part of the administration's advocacy in support of the troop increase.

139. See, e.g., Press Release, Senator Kit Bond, Bond Questions Motivation Behind Disclosure of Vital National Security Information to Media (Feb. 4, 2010), available at http://bond.senate.gov/public/index.cfm?FuseAction=PressRoom.NewsReleases\&Conte ntRecord_id=9A51D6C2-9928-C9A3-FAE3-68770D080E43 (letter to the President from Senator Christopher S. Bond (R-Mo.), Vice Chairman of Senate Intelligence Committee alleges that administration released classified information about cooperation of a terror suspect to defend its policies); Michael A. Fletcher, White House Demands Apology from GOP Senator over National Security Briefing, WASH. POST, Feb. 4, 2010, 
whether or to what extent Administration officials may be suppressing release of damaging information of comparable sensitivity for the purpose of bolstering public support of policy. ${ }^{140}$ Top officials who had articulated facts and opinions that did not support Administration policy have come to embrace the alternative policy, at least, and state it publicly. ${ }^{141}$ Intelligence analysts have not spoken out to question the truth of the facts asserted by the President, which creates the impression that the facts he asserts in support of his threat claims represent the consensus of the intelligence community. Whether this is indeed true is difficult to assess. Members of the Obama executive department are undoubtedly targeting and communicating with private experts for the purpose of influencing the facts and opinions they present in the media. ${ }^{142}$

Although the structures have not changed to prevent this President from using his superior access to intelligence information to support his advocacy, choices he has made, in his advocacy and in the process of decision making, narrow, but do not eliminate, the extent to which he is contemporaneously unaccountable for his threat claims. With respect to advocacy, this President does not rely as extensively as the last one on selected pieces of raw intelligence information to prove the threats that he argues justify the use of force. The Bush Administration relied upon multiple pieces of intelligence information to prove several links in a chain that was necessary to persuade Congress and the public to consent to the use of force ${ }^{143}$ This President's claims of certainty and unanimity are more limited and important links in the chain of persuasion have open source verifica-

http://voices.washingtonpost.com/44/2010/02/white-house-demands-apology-fr.html (White House press secretary explaining that "no classified information was shared when the administration briefed reporters").

140. See Richard B. Cheney, Remarks to the American Enterprise Institute, available at http://www.aei.org/speech/100050 (May 21, 2009) (accusing Obama administration of selectively declassifying Office of Legal Counsel memos that supported enhanced interrogation methods without also releasing information indicating that the methods worked).

141. Both Vice President Biden and Afghanistan Ambassador Eikenberry opposed the troop increase but now support it publicly. Michael Rubin, The Afghanistan Withdrawal: Why Obama Was Wrong to Insist on a Deadline, AM. ENTERPRISE INST FOR PUB. POL'Y RES., Mar. 8, 2010, http://www.aei.org/article/101753.

142. Harris, supra note 119.

143. See, e.g., Colin Powell, Secretary of State, Address to the United Nations Security Council, transcript available at http://www.cnn.com/2003/US/02/05/sprj.irq.powell. transcript/ (Feb. 6, 2003) (presenting multiple pieces of intelligence as proof that Iraq possessed weapons of mass destruction and had the motivation and capability to use them against other nations, including the United States). 
tion. Al-Qaeda, the core threat at which use of force is addressed, has attacked the United States and open source information verifies its intent and potential ability to do it again. ${ }^{144}$ More controversial is the link between the danger to national security posed by al-Qaeda and the necessity to use of force in Afghanistan. The President and other executive branch officials assert this fact with certainty. Intelligence information, which the Administration has not released publicly, undoubtedly bears on this judgment. ${ }^{145}$ We cannot assess its sufficiency, the unanimity with which key assessments are agreed upon by intelligence experts or the credibility of the sources upon which the information depends. To this extent, it is not possible with publicly available information to fully assess the accuracy of the threat claims asserted or the substance of the use of force decision that the President made. ${ }^{146}$

Although we cannot fully assess the information that influenced the substance of the policy choice, the process that this President chose to reach his decision provides some checks on his own use of information control to support his advocacy. This President actively advertised the deliberative process by which the decision to increase troops in Afghanistan was made. ${ }^{147}$ Dur-

144. Anahad O'Connor \& Eric Schmitt, Terror Attempt Seen as Man Tries to Ignite Device on Jet, N.Y. TIMES, DEC. 26, 2009 (Nigerian man arrested for attempting to ignite an explosive device on a plane on Christmas day); Sulzberger \& Rashbaum, supra note 109 (guilty plea in subway bombing plot linked to al-Qaeda); Charlie Savage \& Anahad O'Connor, Pennsylvania Woman Tied to Plot on Cartoonist, N.Y. TIMES, Mar. 10, 2010 (woman going by the name JihadJane and linked to Al Qaeda was arrested in plot to kill a cartoonist); Zeleny, supra note 109 (seven CIA officers were killed in Afghanistan in a suicide bombing linked to al-Qaeda).

145. See, e.g., Spencer Ackerman, supra note 135 ("Janet Napolitano, the secretary of homeland security [sic], said that there was a significant risk that 'recent arrests'-like [Najibullah] Zazi-mean that terrorists have been 'sent here from the border region of Afghanistan and Pakistan to commit more acts of terror.' She said that Zazi's connections to al-Qaeda's senior leadership in that region were 'at most one step removed.' Watch this very carefully. How closely was Zazi actually connected to al-Qaeda senior leadership? How anomalous or indicative is his case? What does his arrest represent about U.S. domestic capabilities relative to those of the al-Qaeda 'syndicate'? And how much information will the Obama administration release to demonstrate the scope of this threat and these ties, as oppose [sic] to asserting them as self-evident?"). Zazi has since pled guilty. Sulzberger \& Rashbaum, supra note 109.

146. Open source information assessing the Afghanistan/Pakistan/al Qaeda threat exists. See, e.g., John Mueller, How Dangerous are the Taliban?, FOREIGN AFF., Apr. 15, 2009, http://www.foreignaffairs.com/articles/64932/john-mueller/how-dangerous-are-thetaliban; Rolf Mowatt-Larssen, Belfer CTR., Al QAeda Weapons of Mass DESTRUCTION THREAT: HYPE OR REALITY? (2010), http://belfercenter.ksg.harvard. edu/publication/19852/al_qaeda_weapons_of_mass_destruction_threat.html.

147. Auletta, supra note $11 \overline{1}$, at 41 (The administration gave interviews to three papers detailing the Afghanistan troop increase deliberation process. The papers were the New York Times, Washington Post and Los Angeles Times). 
ing this time, the President received information and deliberated before commencing his persuasive advocacy in support of policy. ${ }^{148}$ That the President took time, and reviewed many different types of expert information and analyses and listened to a number of different points of view provides some, albeit limited, assurance that the facts he asserts with certainty are supported by the best available evidence. The period of acknowledged deliberation also allowed for fact finding and debate outside the executive branch, by Congress and in the media, before the Administration began its aggressive and persuasive advocacy in support of policy. ${ }^{149}$ That actors outside the executive branch had notice that a decision was to be made provided the opportunity at least for independent, open source development of information, which could compete with threat claims the Administration would ultimately make.

More important than the question of selective use of secret information in support of advocacy is whether the President is exercising his control over the people who gather and analyze intelligence to encourage accuracy independent of the Administration's preferred policy. This is very difficult to assess. The flaws identified by the Senate Select Committee on Intelligence in pre-Iraq War gathering and analysis included failures of analytic tradecraft, lack of information sharing, poor management, inadequate intelligence collection and a "groupthink" dynamic, which caused intelligence community members to conform results to a pre-existing mindset. ${ }^{150}$ The $9 / 11$ Commission identified these and other failings related to information sharing, rivalries and coordination as inhibiting accurate detection and assessment of threats. ${ }^{151}$ It is unclear the extent to which these structural and managerial flaws have been effectively addressed. ${ }^{152}$

148. See Baker, supra note 133 (describing a process that included "a full range of opinions and ... contrary points of view").

149. The Senate Foreign Relations Committee held a public hearing where it took testimony of experts assessing the threat. Confronting Al-Qaeda: Understanding the Threat in Afghanistan and Beyond: Hearing Before the Senate Foreign Relations Comm., 111th Cong. (2009).

150. S. REP. NO. 108-301, supra note 45 , at $15,18$.

151. See NAT'L COMM'N ON TERrorist ATTACKS UPON THE U. S.,The 9/11 COMMISSION REPORT 407-410, http://www.9-11commission.gov/report/911Report.pdf.

152. See, e.g., Thomas H. Kean \& John Framer, Jr., How 12/25 Was Like 9/11, N.Y. TIMES, Jan. 6, 2010 ("Despite the best efforts of the 9/11 commission and other intelligence reformers, budgetary authority over intelligence remains unaligned with substantive responsibility. Turf battles persist among intelligence agencies. Power is sought while responsibility is deflected. The drift toward inertia continues."); Melvin A. Goodman, Op-Ed., President Obama and the Intelligence Community: An Interim Report Card, TRUTHOUT, Nov. 24, 2009, http://www.truthout.org/1124095 (criticizing the President's 
Reforms have been happening, as have critiques of the reforms ${ }^{153}$ Many of the problems that detract from accuracy appear to continue to exist. ${ }^{154}$ What is apparent is that it is very difficult to make deep changes in practices within the vast, dispersed intelligence apparatus ${ }^{155}$ and, because of secrecy, difficult to establish benchmarks and public accountability as to the effectiveness of changes made. What can be said about this Administration is that attention by opposition forces has been directed specifically at the effectiveness of the existing systems for detecting and assessing threats. ${ }^{156}$ This Administration is aware that it will be held accountable for its threat detection results, which should make it attentive to the process. And there is some indication that it is experimenting with new ideas and methods to attempt to enhance accuracy. ${ }^{157}$

It is also difficult to assess the extent to which those who gather and analyze intelligence conform their work to support administration policy. Reports of the President's deliberation process with respect to Afghanistan suggest that he requested intelligence products to answer questions rather than support conclusions. There is no indication that members of the Administration are gathering information outside the existing intelligence process. There appear to be no reports like the few that surfaced before the Iraq War of intelligence analysts feeling

failure to "take a strong leadership role in addressing problems of the CIA").

153. Compare Intelligence Agencies Reel From Attempted Christmas Attack (NPR radio broadcast Jan. 9, 2010), available at http://www.npr.org/templates/story/story. php?storyId=122394478 (Paul Pillar argues that the new structure is probably worse because it adds two more stovepipes) with US Intelligence Reform: Improvement in Counter-Terrorism?, STRATEGIC COMMENTS, Oct. 2007.

154. See, e.g., Kean \& Framer, supra note 152 (procedural fixes that are worth undertaking are "enhanced screening, or installing body scanning technology, or coordinating the software used by intelligence agencies, or instructing State Department personnel to query the visa status of any person reported to be suspicious").

155. See, e.g., Jane Mayer, The Secret History, NEW YORKER, June 22, 2009 (quoting a White House official speaking of the change in Leon Panetta after he took over as CIA director, "It's like 'Invasion of the Body Snatchers.").

156. Peter Baker, Obama's War Over Terror, N.Y. Times MAG, Jan. 17, 2010, at 33 ("When the aviation screening and intelligence systems that Bush built failed to stop ..., [a] Nigerian with ties to Al Qaeda's branch in Yemen, from getting on a plane bound for Detroit with explosives in his underwear . . ., a number of Obama's political opponents blamed the sitting president.").

157. Press Release, Office of the Press Secretary, White House Review Summary Regarding 12/25/2009 Attempted Terrorist Attack (Jan. 7, 2010), available at http://www.whitehouse.gov/the-press-office/white-house-review-summary-regarding12252009-attempted-terrorist-attack; MAJOR GENERAL MICHAEL T. FLYNN ET AL., FIXING INTEL: A BLUEPRINT FOR MAKING INTELLIGENCE RELEVANT IN AFGHANISTAN (2010), available at http://www.cnas.org/files/documents/publications/ AfghanIntel_Flynn_Jan2010_code507_voices.pdf. 
pressured to produce information to support administration policies. Incentives still exist, of course, for agencies and the people in them to produce information that supports administration policy and specifically that demonstrates that threats exist. So long as the heads of the intelligence agencies report to the President, they will have incentives to please him. Their career success will be tied into the success of the President's policies, and they will have incentives to support and defend it, which means that the danger of policy influencing intelligence gathering and analysis will exist.

Incomplete Oversight of the Accuracy of Threat Claims. Although the circumstances and political dynamics are somewhat different, ${ }^{159}$ it is possible to make some observations about the ability and incentives of Congress, the media and private entities to oversee the accuracy of threat claims made by the Obama Administration. With respect to Congress, the institutional disincentives to engage in vigorous oversight of intelligence activities and use of force decision making remain largely the same. ${ }^{160}$ Congressional committees held a number of hearings after the President announced his decision, at which executive department officials testified. ${ }^{161}$ It is unclear what classified informa-

158. See Posting by Michael Isikoff to Declassified blog at Newsweek, Brennan Plays Unusual 'Attack Dog' Role, http://www.newsweek.com/blogs/declassified/2010/02/08/ brennan-plays-unusual-attack-dog-role.html (Feb. 8, 2010) (commenting on appearance of John Brennan, Assistant to the President and Deputy National Security Advisor for Homeland Security and Counterterrorism, on Meet the Press to defend Obama administration counterterrorism policies, noting that "using Brennan in this capacity could have long term risks ... [because] Republicans (and perhaps some journalists) will likely be on guard for any sign he is slanting the intelligence for the president's political advantage").

159. The dynamics of partisan loyalty are shifted somewhat because it is a Democratic president advocating the use of force. See Posner \& Vermeule, supra note 4, at 902 (describing the phenomenon of "counter-partisanship," which is that "presidents have greater credibility when they choose policies that cut against the grain of their party's platform or their own presumed preferences"). But see Patrick Egan \& Joshua Tucker, The Hard Sell, NEw REPUBLIC, Oct. 22, 2009, http://www.tnr.com/article/the-hard-sell ("Democratic presidents like Obama face a particular handicap when making major foreign policy moves [including the use of force].").

160. One change is creation of the United States House Appropriations Select Intelligence Oversight Panel, on January 9, 2007, pursuant to H.R. Res. 35, 110th Cong. (2007) as part of efforts to implement the recommendations of the National Commission on Terrorist Attacks Upon the United States, also known as the "9/11 Commission".

161. Annual Threat Assessment of the U.S. Intelligence Community, supra note 127 (statement of Dennis C. Blair, Director of National Intelligence); Hearing to Receive Testimony on Afghanistan: Hearing Before the S. Comm. on Armed Services, 111th Cong. (2009), available at http://armed-services.senate.gov/Transcripts/2009/12\%20December/ 09-65\%20-\%2012-2-09.pdf (statement of Robert Gates, Secretary, Department of Defense); U.S. Strategy in Afghanistan: Hearing Before the H. Foreign Affairs Comm., 111th Cong. (2009), available at http://foreignaffairs.house.gov/111/53829.pdf (witnesses included Secretary of State Hillary Clinton, Secretary of Defense Robert Gates, Admiral \& 
tion, if any, was made available to Congress members as part of this oversight and the degree to which individual Congress members or staff chose to review and assess it. Much political posturing and some factual inquiry occurred in Congress as the decision was being made. ${ }^{162}$ Focused oversight of the decision, however, could not happen since the President had not announced the decision he would make. The President's control over his own decision making process made effective congressional review of the decision he made difficult, since he began to implement his decision to increase troops immediately upon announcing it rather than inviting a vote by Congress on the decision that he made. ${ }^{163}$

Events during the Obama Administration confirm the potency of threat claims, but indicate that their impact on political debate and oversight of executive branch advocacy and action may be different when the threat claims are made against the Administration and not by it, to support its own policies. While threat claims made by the prior Administration helped insulate it from effective oversight, threat claims made in advocacy against the Obama Administration contributed to political discussion and debate and may have contributed to enhanced oversight of intelligence gathering and threat assessment. In response to the interception and arrest of a suspect allegedly intent on setting off a bomb on a plane bound for the United States on Christmas Day 2009, Republicans and the former Vice President most visibly, mounted a communications campaign advocating that threats exist that the current President does not properly acknowledge and address with appropriate policies. ${ }^{164}$ The for-

\footnotetext{
Chairman of the Joint Chiefs of Staff Michael Mullen).
}

162. See Confronting Al-Qaeda, supra note 149.

163. The President asserted authority to commit troops without a vote by Congress pursuant to the Authorization for Use of Military Force. Pub. L. No. 107-40, 115 Stat. 224 (2001); President Barack Obama, Remarks at the United States Military Academy at West Point, New York, 2009 DAILY COMP. PRES. DOC. 962 (Dec. 1, 2009), available at http://www.whitehouse.gov/the-press-office/remarks-president-address-nation-

way-forward-afghanistan-and-pakistan ("Just days after 9/11, Congress authorized the use of force against $\mathrm{Al}$ Qaeda and those who harbored them, an authorization that continues to this day."). Some Congress members and others argue that a vote is required or appropriate. See Perry Bacon Jr., House Liberals Force Vote on Pullout from Afghanistan, WASH. POST, Mar. 9, 2010, http://www.washingtonpost.com/wp-dyn/content/article/ 2010/03/08/AR2010030803787.html (Rep. Dennis Kucinich introduces resolution and achieves debate and vote on resolution to withdraw troops from Afghanistan); Ackerman \& Hathaway, supra note 110.

164. See Cheney Blasts Obama on Christmas Day Plane Scare, Boston GLOBE, Dec. 30, 2009, http://www.boston.com/news/politics/politicalintelligence/2009/12/cheney_blasts _o.html. 
mer Vice President's charges were perceived by the Administration as potent, and it acted forcefully to rebut them in its communications, including deploying executive department officials into national advocacy roles specifically rebutting charges that the President and his Administration were "weak." ${ }^{165}$ Congressional Democrats worried about the impact of the threat debate on their prospects in the mid-term elections. ${ }^{166}$ Some degree of oversight and change occurred, ${ }^{167}$ although it is unclear how much if any of it can be attributed to the threat claims. What seems more clear is that threat claims are more likely to escape effective fact checking when they are made by members of the executive branch, who also have the authority to control release of the most credible information to support their claims.

Members of the media are ostensibly chastened after their combined failure to effectively fact check the Bush Administration's threat claims with respect to Iraq. ${ }^{168}$ The memory of the recent experience, combined with different circumstances may mean that the current Administration's threat claims may be subject to somewhat greater media oversight. That this President chose to engage in an announced period of deliberation, allowed the media to frame a debate, and present credible and authoritative expert opinions on the facts and the policy before the executive department began its advocacy. ${ }^{169}$ As with Congress, howev-

165. Obama Aides Hit Cheney Comments on Attempted Bombing, Boston GLoBE, Dec. 31, 2009, http://www.boston.com/news/nation/articles/2009/12/31/obama_aides_hit_ cheney_comments_on_attempted_bombing/; John Brennan, Op-Ed., 'We Need No Lectures', USA TODAY, Feb. 9, 2010, at 9A; see also Helene Cooper, The Label Factor: Is Obama a Wimp or a Warrior?, N.Y. TiMES, Jan. 9, 2010, http://www.nytimes. com/2010/01/10/weekinreview/10cooper.html?.

166. Ross Colvin, U.S. Spy Chief in Spotlight After Botched Plane Attack, REUTERS, Dec. 31, 2009, http://www.reuters.com/article/idUSTRE5BT3S820091230 ("Republicans portrayed Obama as weak on national security even as he campaigned for last year's presidential election, and have sought to push that point before mid-term elections in November, when they will challenge the Democrats' control of both houses of the U.S. Congress.").

167. The President acknowledged that the intelligence agencies under his direction had erred, Congress conducted numerous hearings to identify the errors and potential reforms and changes to intelligence gathering structures and methods have been made. Eric Lipton et al., Review of Jet Bomb Plot Shows More Missed Clues, N.Y. TIMES, Jan. 18, 2010, at A1; Mark Guardino, More Changes to Airline Security after Christmas Day Incident, CHRISTIAN SCI. MONITOR, Apr. 2, 2010, available at http://www.csmonitor. com/USA/2010/0402/More-changes-to-airline-security-after-Christmas-Day-incident;

National Intelligence Director to Resign, CBSNEwS.COM, May 20, 2010, http://www.cbsnews.com/stories/2010/05/20/politics/main6503948.shtml.

168. Sherry Ricciardi, Second Time Around, AM. J. REVIEw, Feb./Mar. 2008 ("After their credulous performance in the run-up to the war in Iraq, how are the news media handling the Bush administration's allegations against Iran?").

169. See Jeff Zeleny, Deliberating on Afghanistan, in Plain Sight, N.Y. Times, Oct. 
er, the deeper structures and incentives that operated to deter effective oversight during the last Administration do not appear to have changed. Some media analysts contend that the broadcast and print news coverage is more supportive of the Administration's use of force policy than is public opinion. ${ }^{170}$ Congress members who oppose the war complain that their critique does not get air time or prominent play in print. ${ }^{171}$ Administration sources continue to dominate the news about the use of force in Afghanistan. ${ }^{172}$ This Administration uses more direct communications techniques that allow it to bypass reporters than the last one, and through these media it can control the message that goes out. And, military officials have acknowledged that positive communication to the United States citizenry about the use of force there is crucial to its success, ${ }^{173}$ and can be expected to do all that they can to ensure that reporters deliver the favorable coverage they need.

Some private, organized opposition to the use of force in Afghanistan exists. As with the Iraq War experience, however, these groups to do not have resources or expertise to examine in detail the facts asserted by the Administration in support of its policy. ${ }^{174}$ Research organizations, through publications and websites, can engage in some degree of oversight ${ }^{175}$ Still, the fact that

15, 2009; Where is the Afghanistan Debate? When Public Support Slips, TV Packs in War Boosters, FAIR, Aug. 25, 2009, http://www.fair.org/index.php?page=3886 (Fairness \& Accuracy in Reporting critique on narrow media coverage that ignores public opinion).

170. FAIR, supra note 169 (polls are showing the American public is increasingly more critical of the war in Afghanistan, but media sources are interviewing more and more government officials who are in support of the surge).

171. Kennedy Lashes Out on Afghan War, Media Coverage, Fox News.Com, Mar. 10, 2010, http://www.foxnews.com/politics/2010/03/10/kennedy-lashes-afghan-war-mediacoverage/ (quoting Congress member Patrick Kennedy about reporters' lack of interest in a House resolution requiring debate on whether to continue the war in Afghanistan, "'There's two press people in this gallery,' he shouted. 'We're talking about Eric Massa 24-7 on the TV? We're talking war and peace, $\$ 3$ billion, a thousand lives - and no press? No press?"').

172. Daniel Ward, Act Now, Think Later in Afghanistan; Media Support for 'Surge' Comes Without a Real Plan, FAIR, Apr. 2009, http://www.fair.org/index.php?page=3753 (study of media coverage on the Afghan surge finds that most media outlets support the surge and turn to Pentagon officials to discuss the issue).

173. Jaffe \& Whitlock, supra, note 132, at A09.

174. The contrast between the private funds spent to influence Congress members on the recent health care legislation and on use of force decision making is striking. See Jeff Zeleny, Millions Being Spent to Sway Democrats on Health Care Bill, N. Y. TIMES, Mar. 15, 2010, at A01 (opponents of the President's policy spend over \$11million dollars on advertising in a several week period to influence key Democratic votes; supporters matched that amount during the same time period).

175. E.g., FactCheck.org, http://factcheck.org/ (run by the Annenberg Public Policy Center of the University of Pennsylvania). 
advocacy for use of force consistently does not provoke organized, affluent private interest in fact checking and advocacy against the executive department's position, at least before the commitment of forces is made, points out the heightened importance of other sources of oversight in checking executive department threat claims.

\section{THE PROSPECT FOR FACT CHECKING EXECUTIVE DEPARTMENT THREAT CLAIMS IN SUPPORT OF USE OF FORCE ADVOCACY}

Many observers have criticized the pattern of contemporaneously unaccountable executive branch threat claims supporting advocacy that leads to consent to the use of force, both generally and with respect to the Iraq War specifically. ${ }^{176}$ Many reform proposals have surfaced. These focus on creating new structures or rules to enhance the accuracy of the intelligence product ${ }^{177}$ to encourage executive branch officials to use intelligence accurately in their advocacy ${ }^{178}$ and to require Congress to exercise ongoing and critical judgment with respect to the fact claims made by executive branch officials in support of the use of force policy they advocate. ${ }^{179}$ If implemented and followed, these reforms could help ensure the contemporaneous accountability of executive department threat claims in support of the use of force. ${ }^{180}$ The problem, however, is that mechanisms that

176. See Fisher, supra note 2; see also CATO InSTITUTE, CATO HANDBOOK FOR POLICYMAKERS 110 (7th ed. 2009), available at http://www.cato.org/pubs/handbook/ hb111/hb111-10.pdf (members of Congress "dodge the issue" rather than "take responsibility").

177. See, e.g, Goodman, supra note 53, at 329-56; Stanley Moskowitz, Uncertain Shield; Review of Intelligence in Recent Public Literature by Richard A. Posner, 50 STUD. IN INTELLIGENCE (2007), available at https://www.cia.gov/library/center-for-the-study-ofintelligence/csi-publications/csi-studies/studies/vol50no3/Uncertain_Shield_7.htm (book review); Interview by Greg Bruno with Steven Simon, Adjunct Senior Fellow for Middle Eastern Studies, Council on Foreign Relations (Jan. 6, 2010), available at http://www.cfr.org/publication/21126/connecting_the_dots_on_intelligence_reform.html.

178. The Executive Accountability Act of 2009 would apply criminal penalties to executive officials who knowingly and willfully make misstatements to promote the use of force. H.R. 743, 111th Cong. § 3(a) (2009), available at http://www.govtrack. us/congress/billtext.xpd?bill=h111-743.

179. Miller CTR. OF Pub. Affairs, National War Powers Commission REPORT 6 (2008), available at http://millercenter.org/policy/commissions/warpowers/ report (chaired by former secretaries of state, James A. Baker III and Warren Christopher); Michael J. Glennon, The War Powers Resolution, Once Again, 103 AMER. J. InT'L L. 75, 81 (2009) (describing proposals to reform the War Powers Resolution); Bruce Buchanan, Presidential Accountability for Wars of Choice, BROOKINGS INST. ISSUES IN GOVERNANCE STUD. (Dec. 2008) (proposing a policy trial for use of force modeled on the impeachment process).

180. Promising reforms include increased whistleblower protections for intelligence 
depend upon the will of government actors to enact and abide by them are subject to the incentives that have led to the behaviors that have in the past enabled executive department officials to make threat claims for which they are contemporaneously unaccountable. Additionally, the judiciary cannot be counted upon to enforce structures or rules that apply to use of force decision making ${ }^{181}$ or require the President to release information that he determines should be kept secret to protect the national security. ${ }^{182}$

All of this means that, while new laws that effectively required the many actors in the use of force advocacy and decision making process to do their jobs responsibly might be most desirable, they are also the least likely to be enacted, or implemented in a way that makes them meaningful, at least in the short term. ${ }^{183}$ Without abandoning the hope of more comprehensive reform, some piecemeal progress toward the goal of ensuring the accuracy of executive department threat claims may be achieved by approaching the problem from the public, or listener side, of the communication exchange. Several key recognitions can help those who must ultimately consent to the use of force-members of the public-to evaluate the likely accuracy of executive department threat claims, or at least to assess the extent to which

analysts, Cavanaugh, supra note 21 , at 583; oversight of intelligence activities by a nonpartisan entity such as the Government Accountability Office, House Moves to Increase Oversight of Intelligence Community, OMB WATCH, June 15, 2010, http:// www.ombwatch.org/node/11071, and increased and expert congressional staff focused on intelligence and use of force oversight, MILLER CENTER OF PUBLIC AFFAIRS, supra note 179 , at 47.

181. Miller Center of Public AfFAirs, supra note 179, at 6 ("Despite opportunities to intervene in several inter-branch disputes, courts frequently decline to answer the broader questions [] war powers cases raise."); Barry N. Sweet, Legal Challenges to Presidential Policies on the Use of Military Force, 24 POL'Y STUD. J. 27 (1996) ("The judiciary has been accused of abdicating its responsibility when faced with legal challenges to the presidential use of force (citations omitted). A review of these legal challenges over the last 30 years demonstrates a judicial reluctance to make a ruling on the merits."); Michael J. Glennon, A Conveniently Unlawful War, 150 POL'Y REV. 75, 90 (2008) (noting the "obsequious judicial posture" in war powers cases).

182. See, e.g., Heidi Kitrosser, Secrecy and Separated Powers: Executive Privilege Revisited, 92 IOWA L. REV. 489, 537 (noting "the judiciary's tendency to defer to executive privilege or to related pro-secrecy claims, particularly where national security is involved").

183. See, e.g., Glennon, supra note 179, at 77, 82 (noting that "Congress has already enacted a law requiring the executive to give the Senate Committee on Foreign Relations and the House Committee on Foreign Affairs such information as they may request, without regard to classification, so long as the information relates to activities and responsibilities within their jurisdiction" and that if "Congress truly wants to be included in the decision to go to war ... the constitutional means are available"); CATO INSTITUTE, supra note 176, at 112 ("[L] egislative schemes designed to force Congress to "do the right thing' . . have proved little more effective than a dieter's note on the refrigerator."). 
they are verified, as well as to exercise the power they possess to prod surrogates with greater access or expertise in analyzing the relevant information to do so. ${ }^{184}$

Presidents Speak as Advocates When They Make Threat Claims. Government speech comes in many different varieties. The same person, or entity, can speak at different times, in different ways. The President, in particular, is a public servant who speaks sometimes about facts as an implementer of national policy, and other times, as an advocate for facts that support policies that have not yet been embraced by the Nation's majority. These different types of government speech call on listeners to respond in different ways. The President speaks as an advocate when he presents threat claims to persuade the Nation to consent to the use of force. ${ }^{185}$ This means that listeners must evaluate the claims he makes, and the evidence he presents, as advocacy. While these recognitions may seem obvious, the Iraq War experience suggests widespread confusion among listeners about the President's responsibilities with respect to investigating and presenting evidence that bore on the threat claims he made. It is not unusual that the incentives of a public servant who is also an advocate will be mixed with respect to the presentation of facts that bear upon the decision to be made. In the structured setting of trial, a prophylactic rule can help counter these mixed incentives and address the imbalance in access to information in aid of more accurate fact finding and decision making. ${ }^{186}$ Solutions are

184. Checklists can lead to concrete results even when their contents are very basic. Cf. Atul Gawande, Op-Ed., A Lifesaving Checklist, N.Y. TimES, Dec. 30, 2007, 4-8 (noting "stunning" results of a simple five-point checklist reminder in preventing hospital infections).

185. Presidents select information to present for the purpose of influencing those deliberations in favor of their preferred policies, and they employ speech writers who are professionally trained to use words and images that go beyond reason and logic to invoke emotions for maximum persuasive effect. See, e.g., BEST, supra note 17, at 6 ("One problem [with the use of intelligence information by policymakers] might be that the process by which White House speeches are drafted is less sensitive to the complexities of intelligence analysis than the policy-making processes of the National Security Council.”).

186. In the trial context, the Supreme Court has recognized that prosecutors bear these conflicting responsibilities. On the one hand, they are to protect the public by identifying criminals and obtaining convictions. On the other hand, they are "the representative $[\mathrm{s}] \ldots$ of a sovereignty . . . whose interest . . . in a criminal prosecution is not that it shall win a case, but that justice shall be done." Kyles v. Whitley, 514 U.S. 419, 439 (1995) (quoting Berger v. United States, 295 U.S. 78, 88 (1935)). Because of these conflicting incentives, to effectuate the Constitution's due process guarantee, the Court has imposed a prophylactic rule that requires prosecutors to deliver potentially exculpatory evidence to defendants. See Brady v. Maryland, 373 U.S. 83 (1963). The prophylactic rule is designed, through the mechanism of information release, to "preserve the [constitutionally designated fact finding arena], as distinct from the [government advocate's] private deliberations, as the chosen forum for ascertaining the truth about [the policy matter to be 
less obvious in the context of public advocacy and decision making. At least, the recognition that threat claims in support of the use of force are evidence in support of advocacy may instill the appropriate critical response by public listeners, who as fact finders must attempt, through congressional or media inquiry or otherwise, to verify the threat claims that are made.

Process Can Provide Clues as to the Value of Intelligence Information Offered in Support of Threat Claims Even If Its Substance Remains Secret. The President's control over the gathering and content of intelligence information is highly significant to his ability to make persuasive threat claims in support of the use of force. To a certain extent, the President simply cannot be held contemporaneously accountable for the specific content of the threat claims he makes. ${ }^{187}$ Nevertheless, a few basic understandings about the process of reaching intelligence assessments, which is special, and about the nature of the raw intelligence, which is not so special, can be applied to executive department threat claims to help narrow the range of their contemporaneous unaccountability.

Intelligence assessments are special because they use raw information gathered in range and depth that private entities cannot rival, apply expert judgments that make use of experience, expertise, and multiple perspectives, and reach assessments that are as factually accurate as they can be without respect to how they bear on policy choices. Certainly, the process does not and cannot ever work perfectly. A process directed toward accuracy can, however, work better than a process that directs fact gathering and assessment in support of policy. When the President makes threat claims to obtain consent to the use of force, it is possible, even without contemporaneous access to the content of the raw information or intelligence assessments, to make some judgments about whether the threat assessments asserted were reached through a process that carries the best possibility of ensuring accuracy. ${ }^{188}$ While members of the public can ask these

decided.]" Kyles, 514 U.S. at 440.

187. See, e.g., Glennon, supra note 179, at 77 ("Given the historical disinclination of the executive to share information with Congress, it is unduly optimistic to believe that [even a committee specifically charged by statute with the responsibility of consulting with the President about the use of force] would ever have access to all the information necessary to make an informed, balanced judgment in a crisis.").

188. Examples of relevant questions that can be answered with open source information include: When does it appear that the President decided to use force? Did the threat assessments available at that time justify the conclusion reached? Did the threat assessments change substantially over a short period of time, and if so, why? Are there any in- 
questions and obtain some answers without assistance, they can also use the power they wield over Congress members or members of the media to use their special access to information and sources to examine the process by which intelligence information is being produced and offered by the executive branch in support of policy.

While the process of intelligence gathering and assessment is special, the other important understanding is that raw intelligence presented outside the context of analysis is not so special. Certainly, intelligence agencies have access to the widest range of information and, combined, have the best ability to reach an accurate intelligence product. But one important lesson of the Iraq War experience is that the two activities of intelligence gathering and expert analysis must go together to produce a quality product. Pieces of raw intelligence presented to non-experts outside the context of analysis can be highly misleading if understood to be certain proof of what they seem to show rather than as the selected fact presentation of an advocate. In the controlled arena of trial, checks exist to allow the fact finder to assess the credibility and significance of the many pieces of raw evidence presented to prove the case. Of course, public decision making is not a trial, and the President has the actual or practical authority to keep much of the intelligence information that bears on threat claims secret. Nevertheless, some clues as to the credibility and significance of pieces of raw intelligence can be gained by inquiring indirectly, not as to the specifics of sources or content, but as to the process by which the information was obtained, deemed significant to threat assessment ${ }^{190}$ and made public to support the President's proposed policy.

dications of unusual contact between policy makers and intelligence analysts? Are there any indications that raw intelligence is being gathered or released by policy makers without having been vetted through the process that applies in the intelligence community? More generally, has the President acted in a way that indicates confidence in the ability of the intelligence community to reach accurate assessments, and indicates a continuing intent to take actions to improve and rely upon the products it produces?

189. See Paul R. Pillar, Pillar to Press: Don't Be Fooled Again, NiEman WATCHDOG, Feb. 27, 2006, http://www.niemanwatchdog.org/index.cfm?fuseaction= ask_this.view\&askthisid=00181 (proposing questions for members of the media to ask when executive branch officials use intelligence information to support their advocacy).

190. Relevant inquiries pertain to the degree of consensus within the intelligence community and whether the most expert agencies agree with the assessment put forth in executive department advocacy. See S. REP. NO. 108-301, supra note 45, at 28 (noting that Central Intelligence Agency analysts several times ignored judgments of more expert intelligence units on the meaning and significance of raw information). 
Citizens Can Impact the Incentives of Surrogates to Fact Check Threat Claims. Because incentives impact oversight of executive department threat claims so substantially, it makes sense to try to locate where they operate and to try to imagine ways to impact them even slightly. When executive branch officials exaggerate threat claims, they depend upon the lack of ability or incentive of others to engage in effective fact checking before the decision to use force is made. ${ }^{191}$ This interdependency means that any action to enhance contemporaneous fact checking will impact the incentives of executive department officials to assert unverified threat claims in the first place. One small, but potentially effective oversight activity would be to flip the successful executive branch communications technique of quickly identifying misstatements and correcting them before the misstated information becomes cemented in the public's minds. ${ }^{192}$ Some media and web-based organizations do this sporadically. ${ }^{193}$ A more sustained effort could potentially impact the incentives of executive branch officials to overstate facts in their advocacy. ${ }^{194}$ Another point of entry for citizen action is timing. The shorter the time period between when the use of force question is framed for debate and the decision making, the less likely facts asserted by the executive department in its advocacy can be checked effectively. This recognition suggests that those being asked to consent to the use of force be skeptical of claims of urgency, and demand the time necessary to ask questions about the evidence presented and receive the answers.

One reason that Congress members make the choice not to actively fact check administration threat claims because they calculate that the electoral punishment for opposing a successful use of force will be greater than the punishment for failing to engage in effective oversight. This incentive is difficult to undermine directly. An additional incentive, however, may be more susceptible to change. Congress members seem to calculate that, among the many choices they have about how to spend their

191. See SCHUESSLER supra note 20 , at 21 ("[P]ro-war elites . . . take a calculated risk that victory will be decisive [and so they] will be subject to little scrutiny about how they maneuvered the country to war.").

192. Auletta, supra note 111 ("Once a story gains traction, [Obama administration chief communications officer Anita Dunn] says, the Administration must respond quickly or 'rumors become facts."').

193. See, e.g., FactCheck.org, http://factcheck.org/; see also Organization of News Ombudsmen, http://www.newsombudsmen.org/what.htm (media fact checking site).

194. But see Brendan Nyhan, Op-Ed., The Fight Is Over, the Myths Remain, N.Y. TIMES, Mar. 25, 2010, at A31 (research shows highly ideological listeners may believe incorrect information more strongly after it is rebutted). 
time and public capital, the electoral rewards for diligent oversight of executive department threat claims, and intelligence and use of force activities more generally, are slight. Change requires finding ways to make individual Congress members with the responsibility to oversee executive department threat claims, and intelligence and use of force activities, believe that their constituents will notice if they do the job well or poorly. Obviously, these methods, too, are hard to identify. But transparency and education are tools that could alter the dynamic somewhat. Some public education about Congress's oversight responsibilities could help change assumptions about what Congress members should have to explain. Congress members react to being called out publicly for their behavior. ${ }^{195}$ When intelligence lapses happen, Congress members with responsibility for oversight should be named and asked to identify and explain the oversight actions engaged in on their watch. ${ }^{196}$ On the carrot side, perhaps there is some way to identify and reward hard work that particular Congress members do, even if it is done behind closed doors. ${ }^{197}$ All of these moves are difficult to accomplish, but the Iraq War experience suggests that even slight changes in incentives can make a difference in how members of Congress behave with respect to executive department threat claims.

Media incentives are financial, and the incentives of reporters and media personalities is driven in large part by market forces as well, which means that both are difficult for citizens to influence to lead to more critical and careful coverage of executive department threat claims. Pressure from affluent advertisers may tend the opposite way. ${ }^{198}$ Many media entities police themselves. ${ }^{199}$ And, media watchdogs help to monitor media coverage

195. See, e.g., Carl Hulse, Senate Ends an Impasse Over Extending Jobless Benefits, N.Y. Times, Mar. 3, 2010, at A13 (Kentucky Senator Jim Bunning dropped objection to the extension of unemployment after other Republicans began to voice concerns on how the block would damage their "political brand").

196. See, e.g., Andrea Seabrook, Congress Under Scrutiny Over Plane Bomb Plot, NPR, Jan. 8, 2010, http://www.npr.org/templates/story/story.php?storyId=122372392 (claiming, without naming names, that several members of the $9 / 11$ commission "say Congress should be delving into its own mistakes, too" in failing to engage in oversight that might have detected intelligence gathering and analysis problems that allowed the attempted bombing to occur).

197. Media profiles are a possibility. See, e.g., Peter Baker, The Limits of Rahmism, N.Y. Times MAG., Mar. 14, 2010, at 36 (New York Times Magazine profile of Rahm Emanuel).

198. See Buying the War, supra note 90 (citing advertisers calling TV stations about anti-war coverage).

199. Many newspapers have ombudsmen who comment on their paper's coverage. See, e.g, Organization of News Ombudsmen, http://www.newsombudsmen.org/what.htm. 
of executive department advocacy. ${ }^{200}$ Even if it is difficult for citizens to impact media incentives directly, citizens can take some types of indirect action to preserve the possibility of a media check on executive department threat claims. One of these is to preserve the possibility of professional, expert media fact evaluation and delivery as an alternative to direct executive department advocacy. Presidents commonly complain about "media filters" and work to get their messages out to the public unmodified. ${ }^{201}$ While reporters as a source of oversight are imperfect, the Iraq experience and events during the Obama Administration confirm that journalist intermediaries remain an important alternate source of information to add balance to the increasingly ubiquitous direct media means of message delivery. Citizens can realize this, and vote with their dollars and their readership to preserve the content, even as the form modernizes. ${ }^{202}$

\section{CONCLUSION}

Too often Presidents have persuaded the Nation to consent to the use of force by making exaggerated threat claims. Although some increased indicators of accuracy exist during the current presidency, that the threat claims depend in part on secret intelligence information means that we cannot know for sure whether this is again happening. What we do know is that this President, like every one who came before him, is an advocate, which means he will craft his presentation of facts to persuade the public to embrace his preferred policy. And the structures, incentives and behaviors that allowed members of the previous Administration to inflate threat claims remain largely the same. While it makes sense to work toward legal change, as an interim measure, it is necessary for the targets of executive branch advocacy to be aware that the facts presidents present will inevitably be inextricably intertwined with their advocacy, that threat claims in support of the use of force particularly im-

200. See, e.g., Nieman Watchdog, Nieman Foundation for Journalism, http://www. niemanwatchdog.org/; FAIR, Fairness and Accuracy in Reporting, http://www.fair.org.

201. Jonathan Martin, Obama Seeks Filter-Free News, POLITICO, Mar. 24, 2009, http://www.politico.com/news/stories/0309/20395.html ("It is the perennial hope of presidents-especially early in their administrations - that they can escape the filter of an often-skeptical Washington press corps and communicate directly with a target audience.").

202. David Bauder, Survey: Readers Don't Want to Pay for News Online, MYWAY, Mar. 14, 2010, http://apnews.myway.com/article/20100315/D9EER6CG0.html (journalism study showing how readership of papers is holding steady even though the means of delivery is the internet not print). 
pact the incentives and behaviors of entities that could oversee the accuracy of those claims, and that such claims must be fact checked somehow to preserve democratic decision making. 